\title{
REGIONAL NONADJUSTMENT AND
}

FISCAL POLICY: LESSONS FOR EMU

\author{
Maurice Obstfeld \\ Giovanni Peri
}

Working Paper 6431 
NBER WORKING PAPER SERIES

REGIONAL NONADJUSTMENT AND

FISCAL POLICY: LESSONS FOR EMU

\author{
Maurice Obstfeld \\ Giovanni Peri
}

Working Paper 6431

http://www.nber.org/papers/w6431

\title{
NATIONAL BUREAU OF ECONOMIC RESEARCH \\ 1050 Massachusetts Avenue \\ Cambridge, MA 02138 \\ February 1998
}

We thank Reza Baqir, Ryan Edwards, and Stefan Palmqvist for excellent research assistance. Tamim Bayoumi, Giovanni Favara, Ingo Fender, Larry Katz, Paul Masson, Chris Salmon, and Till von Wachter offered valuable help in locating and organizing data. Olivier Blanchard, David Card, Barry Eichengreen, Antonio Fatás, Peter Kenen, Barry McCormick, Jacques Mélitz, Andrew Oswald, Frédéric Zumer, and especially Jürgen von Hagen have made many very helpful suggestions, as did participants in the October 1997 Economic Policy panel meeting in Bonn and the Berkeley Labor Lunch. All errors and opinions are our own. Research support was provided by the National Science Foundation (through a grant to the National Bureau of Economic Research), the Alfred P. Sloan Foundation, and the Center for German and European Studies at the University of California, Berkeley. Any opinions expressed are those of the authors and not those of the Congressional Budget Office or the National Bureau of Economic Research.

(C) 1998 by Maurice Obstfeld and Giovanni Peri. All rights reserved. Short sections of text, not to exceed two paragraphs, may be quoted without explicit permission provided that full credit, including (C) notice, is given to the source. 
Regional Nonadjustment and Fiscal Policy:

Lessons for EMU

Maurice Obstfeld and Giovanni Peri

NBER Working Paper No. 6431

February 1998

JEL Nos. F4, J61, H77, E44

\section{ABSTRACT}

How will countries handle idiosyncratic national macroeconomic shocks under the European single currency? The ways in which European countries now react to internally asymmetric shocks provide a better forecast than do the regional response patterns of the United States. In this paper we compare the US with Germany, Italy, the United Kingdom, and also with Canada, which is closer to Europe than the US is in its labor market and fiscal institutions. Europe's (and to some extent Canada's) model of regional response differs from that of the US. Changes in relative regional real exchange rates are generally small. Outside of the US, however, there is more reliance on interregional transfer payments, less on labor migration, and the pace of regional adjustment appears slower. The regional adjustment patterns currently prevailing within European currency unions-characterized by limited labor mobility and price inflexibility--seem likely to prevail at the national level under the single currency. If EMU aims to attain the economic and social cohesion of its constituent nations, it therefore may be hard to resist the eventual extension of existing EU mechanisms of income redistribution--a transfer union. We propose an alternative strategy based on a relaxed stability pact, further strictures against central EU borrowing, labor market and fiscal reform, and the issuance by individual member states of debt indexed to nominal GDP.

Maurice Obstfeld

Department of Economics

University of California, Berkeley

Berkeley, CA 94720-3880

and NBER

obstfeld@econ.berkeley.edu
Giovanni Peri

Department of Economics

University of California, Berkeley

Berkeley, CA 94720-3880

giovanni@econ.berkeley.edu 


\section{Introduction}

How will members of Europe's economic and monetary union (EMU) adjust to asymmetric macroeconomic shocks after the single currency is in place? On the eve of the third and final stage of EMU, considerable uncertainty over the answer remains, despite nearly three decades of research. $^{1}$

Much of that research has tried to distill lessons for Europe by studying the performance of existing currency unions. In this paper we extend this evidence and review some of its main findings, in the process identifying key areas in which definitive conclusions remain elusive. On the basis of our interpretation, we advance some conjectural scenarios for macroeconomic adjustment patterns in the euro zone.

Given its overall satisfactory economic performance and political stability, the United States has been the natural starting point for research into intranational adjustment mechanisms. Sometimes the US is taken as a model for predicting integrated Europe's evolution. More often, it serves as an exemplar of regional adjustment or insurance mechanisms that at present appear largely absent among prospective EMU members, but may need to evolve to ensure the union's success. The key regional adjustment mechanisms are labor mobility and local relative price responses, whereas the main insurance mechanism, alongside private capital markets, is based on interregional transfer payments mediated by the central government.

In this paper the focus is instead to compare the internal adjustment patterns European countries display with those of the US. We also look at Canada, which is closer to Europe in its labor market and fiscal institutions than the United States is. A direct comparison of the US with 
other currency unions is revealing. It suggests that Europe's (and to some extent Canada's) model of regional response to idiosyncratic shocks differs from that in the US. Changes in relative regional real exchange rates are generally small. Outside of the US, however, there is more reliance on interregional transfer payments, less on interregional labor migration, and the overall pace of regional adjustment appears slower. The large and continuing transfers from western to eastern Germany, where open unemployment still runs around 18 percent, represent a notably pathological example of this tendency.

Ultimately EMU may lead to changes in the institutions governing economic relations within and between European Union member states. Given those institutions, however, the subnational economic adjustment patterns of European countries offer a better guide than the US does to how the euro currency area is likely to evolve. One goal of the paper is to ask whether regional response patterns typical of individual European economies are likely to emerge at the EMU level. Another goal is to judge the past performance of the European countries themselves as currency unions. The implication for EMU of this assessment is immediate. Because countryspecific shocks often affect subnational regions differently, sluggish regional adjustment, if uncorrected by policy reforms, will worsen the pain they inflict, and thereby complicate life under the single currency.

The plan of the paper is as follows. Section 2 reviews the main mechanisms of adjustment and insurance available to a region or country hit by an idiosyncratic economic shock. An overview of data for the US, Canada, and some EU members is suggestive of national differences in the primary modes of response to shocks. In section 3 we look more closely at regional unemployment data, observing that local unemployment persistence is higher outside the United 
States and that interregional migration plays a much smaller role in adjustment in Europe than in the US. Section 4 takes up regional relative price adjustment as an element in the return to full employment after a shock. In none of the countries we examine does regional relative price adjustment play a large role when compared with the long-term changes in international relative prices that one commonly observes. The reasons for this contrast are uncertain and surely differ across countries. But the slow adjustment of regional labor markets in European countries suggests that the low variability of their interregional real exchange rates partly reflects price rigidities that impede adjustment, rather than the efficient operation of natural currency areas. By preventing large relative-price changes, such price rigidities may support the political viability of free trade within currency unions.

The extent of regional risk-sharing through capital markets and especially through government transfer payments has received considerable attention in research on currency unions, starting with the estimates on fiscal redistribution and stabilization in the influential MacDougall Report (Commission of the European Communities 1977). In section 5 we review this literature and conclude that fiscal transfers play a central role in supporting existing currency unions, albeit less so in the US, where labor is most mobile, than in Canada and Europe. A main point of our discussion is that transfers tend to be quite persistent and sometimes to respond to shocks with lags. Indeed, though various mechanisms, transfer programs intended to provide social insurance may lengthen the adjustment process and, in extreme cases, induce regional dependence on fiscal inflows. Thus, we argue that sharp distinction the literature has made between the redistribution and stabilization functions of fiscal transfers, while conceptually valid, is overdrawn in practice. Given the central role of fiscal transfer systems in other currency unions, we are led to ask, in 
section 6, whether the EMU countries will inevitably see a need to augment substantially current EU transfer programs. Our conclusion is that it will become hard to resist pressures for a more extensive 'transfer union', especially if the EU wishes to pursue deeper and broader political or economic integration in the face of existing national income disparities. That conclusion leads us to propose a set of alternative measures that could reproduce the benefits of an extended transfer mechanism while avoiding many of its pitfalls.

\section{Adjustment and insurance: questions and trends}

\subsection{Mechanisms of adjustment and stabilization}

A country suffering an unexpected adverse real economic shock has several options for response when domestic market rigidities generate higher unemployment. Options that are attractive in the face of a transitory shock may be less so when the shock is permanent, or highly persistent. In the latter case, the country faces a problem of long-run adjustment to a permanently lower standard of living. In the former, it faces a less severe financing problem, that of cushioning employment and output in the face of transitory bad luck.

National fiscal stabilizers, either discretionary or automatic, can be helpful in riding out temporary real shocks. So can private external borrowing. A country with a flexible exchange rate may gain from currency depreciation. However, a temporary disturbance generally warrants a relatively small (and short-lived) depreciation, and a currency participating in an adjustable peg system would not normally realign. For that reason, the prospect of temporary disturbances is of secondary relevance in comparing the merits of outright currency union with those of an adjustable-peg regime such as the European Monetary System. ${ }^{2}$ 
When a negative real shock is permanent, however, there are no options for cushioning its impact over the long term, simply because a country cannot live outside its long-run budget constraint. Solvency constraints rule out using permanently higher fiscal or external deficits to maintain public or private spending (Corden 1972; Krugman 1993).

Thus, there is no choice but adjustment, and adjustment can occur in one of two ways (absent significant international labor mobility). The first option is to do nothing and rely on deflation and falling real wages to restore full employment, possibly a long and agonizing process marked by persistently high joblessness. The second is to devalue the domestic currency. If there is some nominal stickiness in prices and wages, and room for real wage adjustment as well, a country can devalue its currency, thereby making its goods more competitive internationally and restoring full employment quickly. Importantly, devaluation does not enable a country to escape a long-run real income loss. But although the country's terms of trade worsen permanently and immediately, that loss is widely shared by residents and is widely viewed as preferable to the fiscal drain and social tensions that protracted unemployment causes. Moreover, and quite fundamentally, the currency realignment leads to a more efficient national and international allocation of resources.

As noted, the existence of a devaluation option depends not only on some nominal wage or price stickiness, but also on some willingness of domestic price setters to accept an exchangerate induced reduction in their real incomes as a fait accompli. Without this prerequisite, devaluation will have only short-lived relative-price effects that are quickly offset by higher domestic inflation (Hinshaw 1951; McKinnon 1963). After this surge of inflation the price level and real wages will fall as the economy gradually adjusts to its worsened terms of trade. In the 
case of substantial real wage resistance, there is therefore no short-cut through devaluation: only a lengthy period of high unemployment will bring about the necessary fall in real wages. The real effects of devaluation tend to be weaker in smaller and more open economies.

A country that can enter private insurance arrangements with foreigners (equity contracts, for example) can partially guard against permanent and transitory shocks alike. In the case of a temporary shock, protection through insurance contracts may be more effective than borrowing, which must be repaid irrespective of the economy's future performance. Even when a permanent adverse national shock occurs, a permanently lower level of real net dividend outflows affords some offset. In practice, however, labor income is vastly less insurable than capital income, so the benefits from cross-border insurance arrangements accrue disproportionately to those who own internationally diversified financial wealth. At best, the resulting dividend payments affect labor incomes and employment indirectly. Exchange-rate adjustments thus remain potentially useful as a way of regaining full employment and redistributing domestically the pain of adjustment to permanent adverse shocks.

Regions within a currency union plainly lack the devaluation option after a permanent region-specific setback, but may be able to obtain persistent and even permanent streams of inward net transfer payments from more fortunate regions. To some degree these transfers represent private intranational insurance payments, but in modern economies governmentintermediated redistributions from other regions also bulk large. Public transfers support the incomes of the unemployed and enhance local demand, in theory substituting for outward migration, which is a major adjustment mechanism within national units if not always between them. Short-lived inward transfers, like local fiscal expansion, can play a stabilization role by 
cushioning the initial impacts of adverse shocks. Open-ended transfers also stabilize, but they are not a mode of regional adjustment to permanent shocks. Instead they finance regional nonadjustment indefinitely.

\subsection{Regional unemployment, inflation, and fiscal flows}

An overview of regional unemployment trends in some existing currency unions provides a backdrop for the closer analyses of regional economic adjustment described in the following sections. The data provide hints about both the speed of adjustment and international differences in intranational adjustment patterns.

Several authors have looked at the dispersion of regional unemployment rates to assess both the incidence of regionally asymmetric shocks and the speed of adjustment to them (Eichengreen 1990, 1991; Emerson et al. 1992; De Grauwe and Vanhaverbeke 1993; Masson and Taylor 1993; Viñals and Jimeno 1996). An initial fact important in comparing the behaviors of different currency unions is that the regional divergence in unemployment rates is relatively low in the United States, with little tendency to increase secularly. Figures 1 and 2 plot, respectively, standard deviations and coefficients of variation (standard deviations divided by means) for regional unemployment rates.

Shown for comparison are data from Canada, Germany, Italy, the UK, the US, and the 'EU11'--the signers of the Maastricht Treaty other than Luxembourg. Italy stands out for its sharply increasing regional unemployment-rate disparities, which are much more severe even than those among the EU11. Dispersion in the UK also was relatively high until the mid-1980s, and its drop afterward, notwithstanding the recession of the early 1990s, is remarkable. ${ }^{3}$ In Canada 


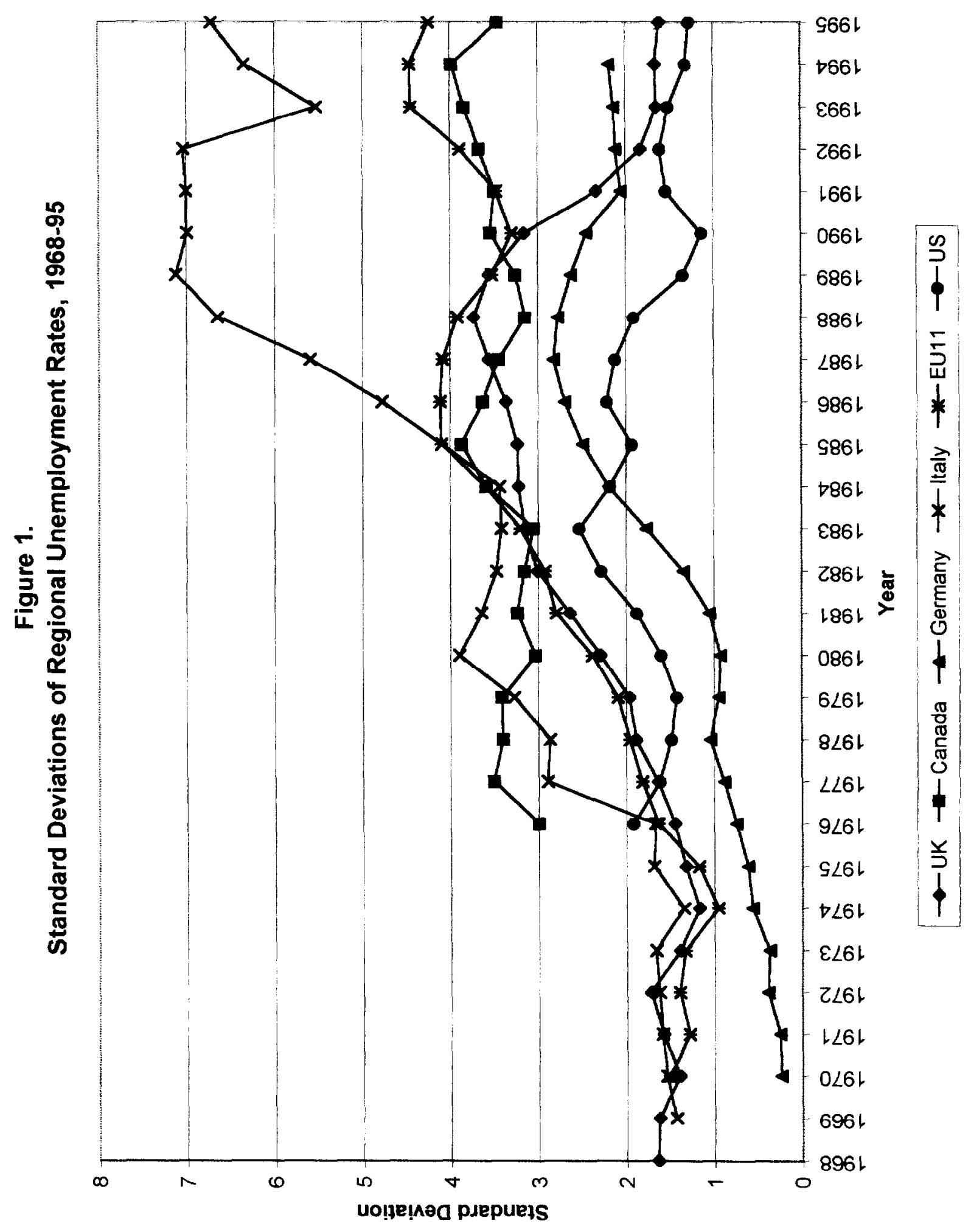




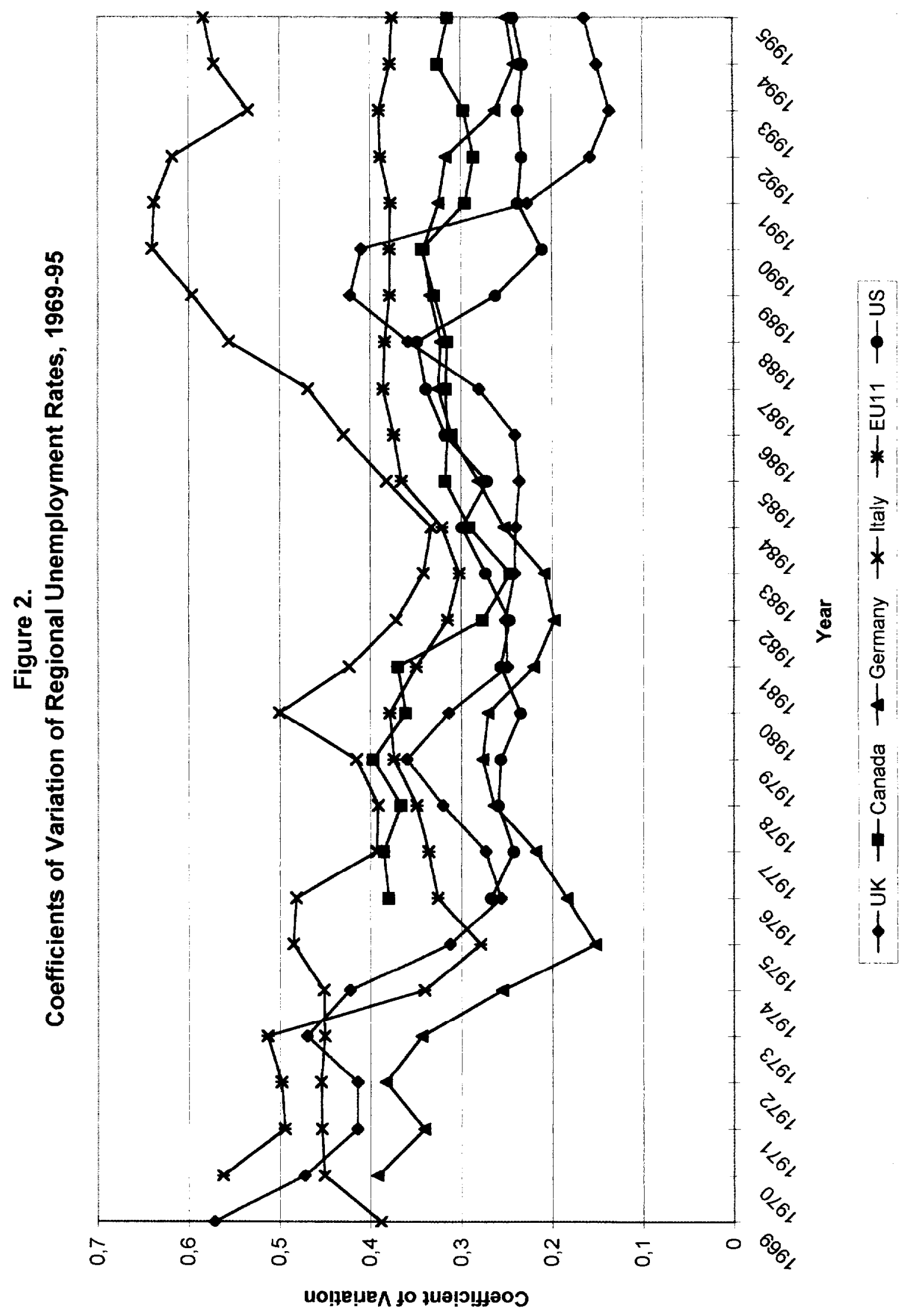


unemployment dispersion has been relatively high but steady for many years. In Germany it has been relatively low among the western Länder included in figures 1 and 2, but has risen over time on a simple standard deviation measure, and would appear higher still were eastern Germany included. The coefficient of variation for western Länder remains fairly constant in recent years because overall western unemployment has risen sharply. Overall, Germany's unemployment dispersion seems intermediate between that of the US and the EU11, and in recent years it looks quite similar to that of the EU11 minus Spain. ${ }^{4}$

Patterns of unemployment dispersion have been persistent outside the US, in the sense that the regions of relatively high unemployment have tended to remain the same over time. This feature is evident in figures 3-6, which show the evolution of regional unemployment rates for Canada and the three European countries.

To document the contrast with US regional unemployment behavior, figures 7-11 show scatter plots of regional relative unemployment rates in 1995 against 1985 rates. (For Germany the years compared are 1994 and 1984.) The plots in figures 7-10 show significantly positively correlated unemployment rates in the two periods. For the case of American states illustrated in figure 11 , there is a less strongly significant positive relationship with a much lower $R^{2}$ statistic, suggesting less history-dependence in US regional unemployment rates. ${ }^{5}$

The estimated intertemporal correlations in these figures do not allow us, however, to distinguish between two explanations with somewhat different implications for evaluating regional macroeconomic adjustment speeds. A region may have a persistently high 'natural' rate of unemployment, resulting from differences in industrial mix, urbanization, unemployment benefit administration, and so on. On the other hand, slow adjustment to regional shocks is reflected in 


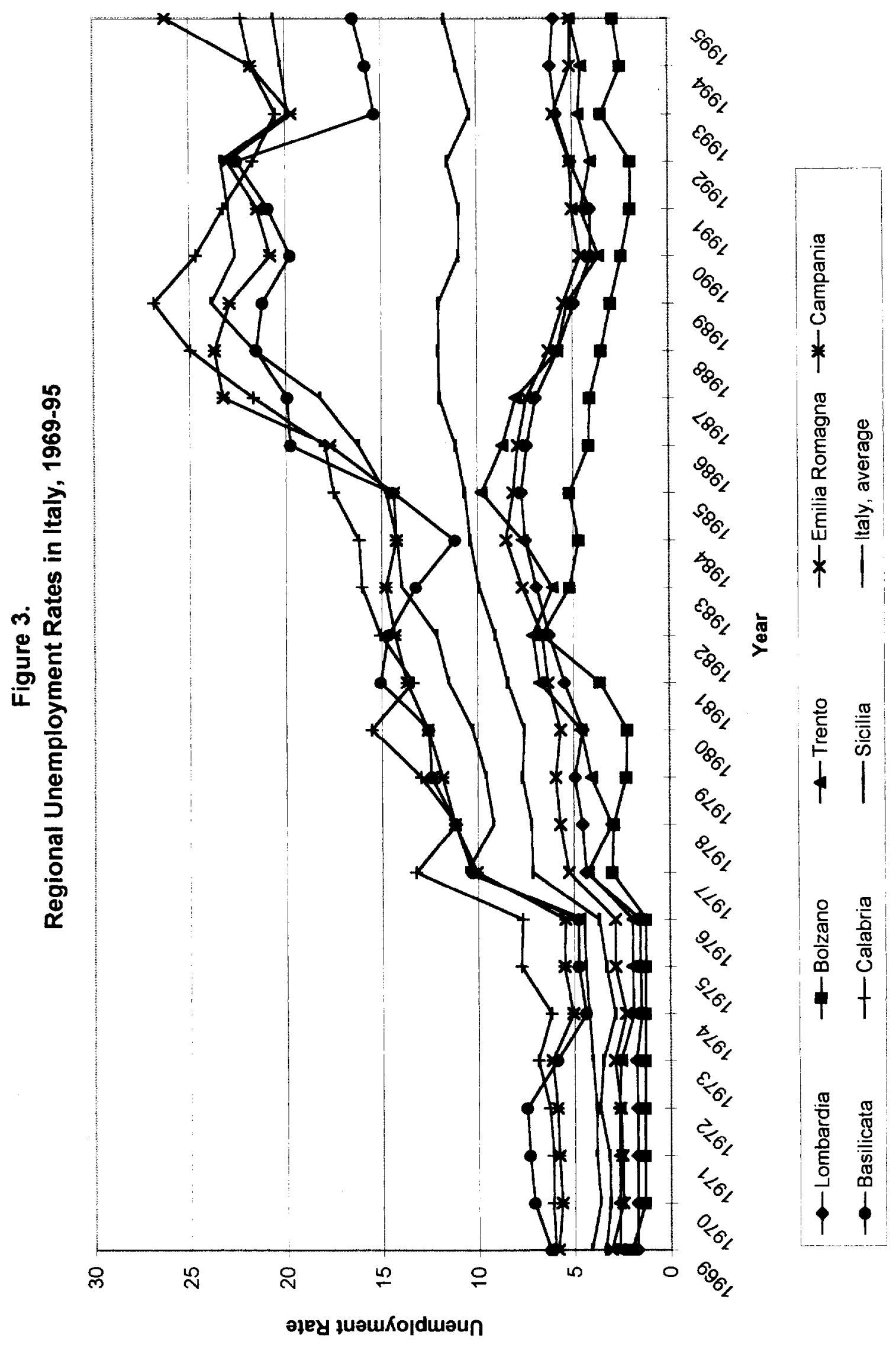




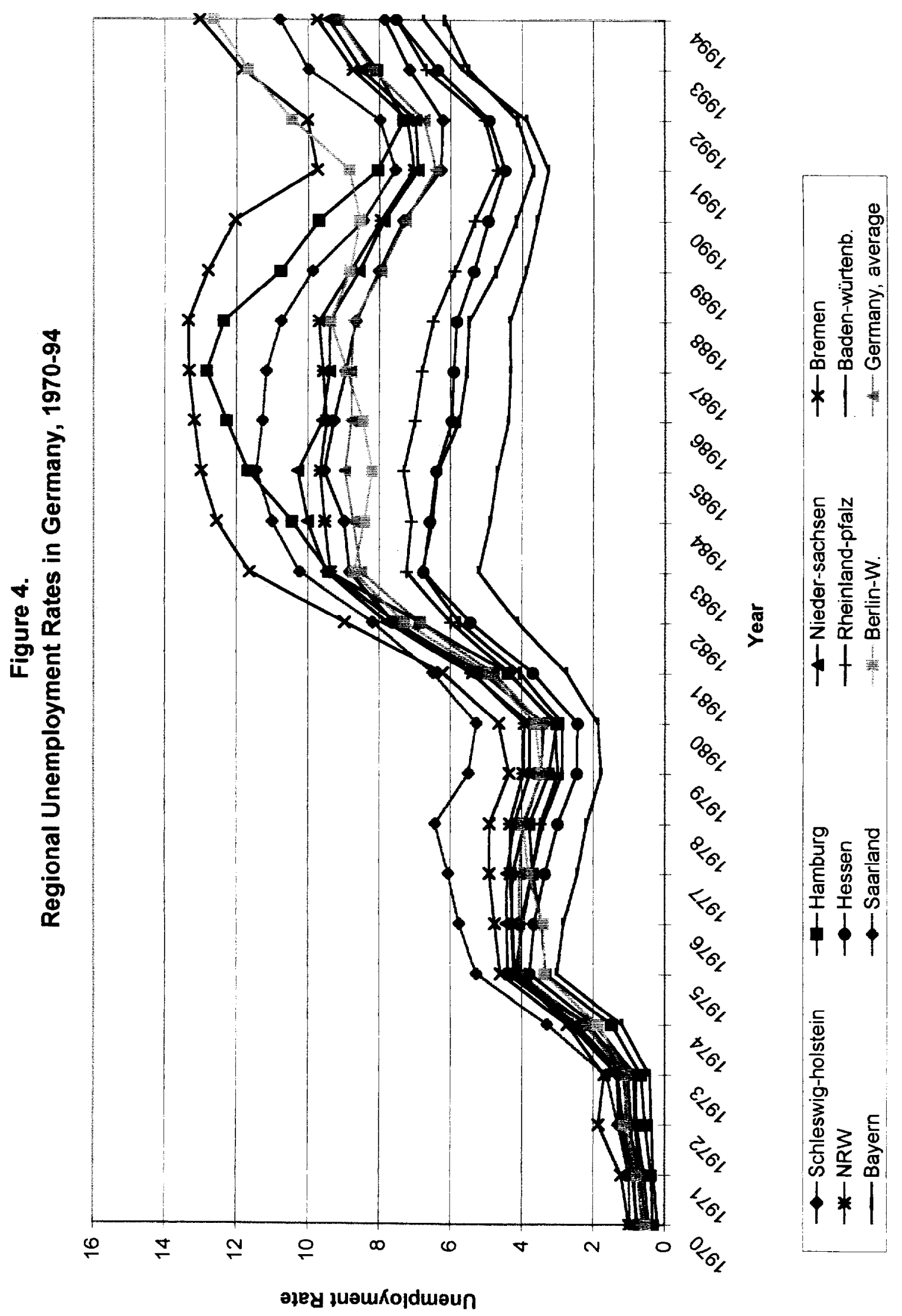




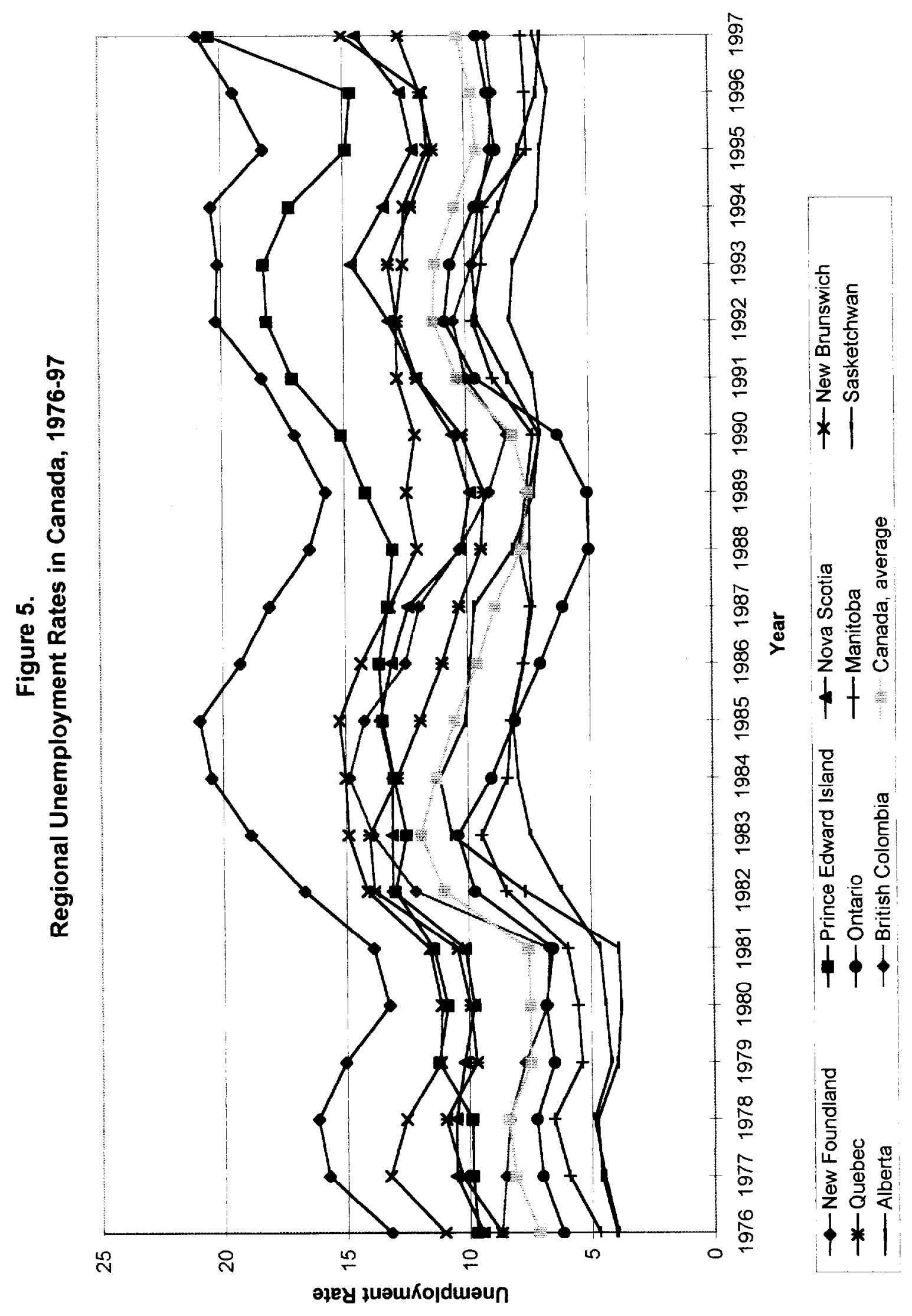




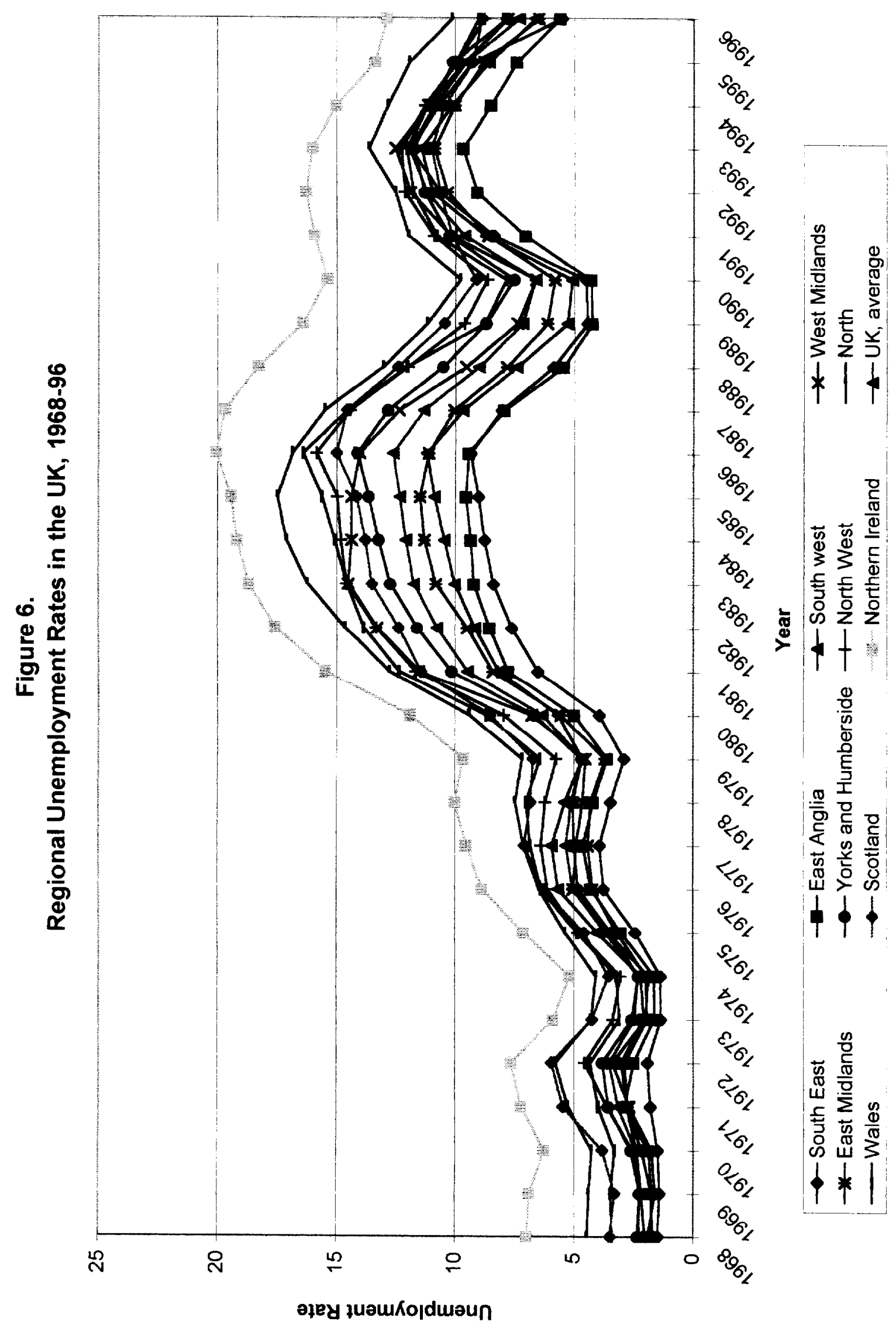




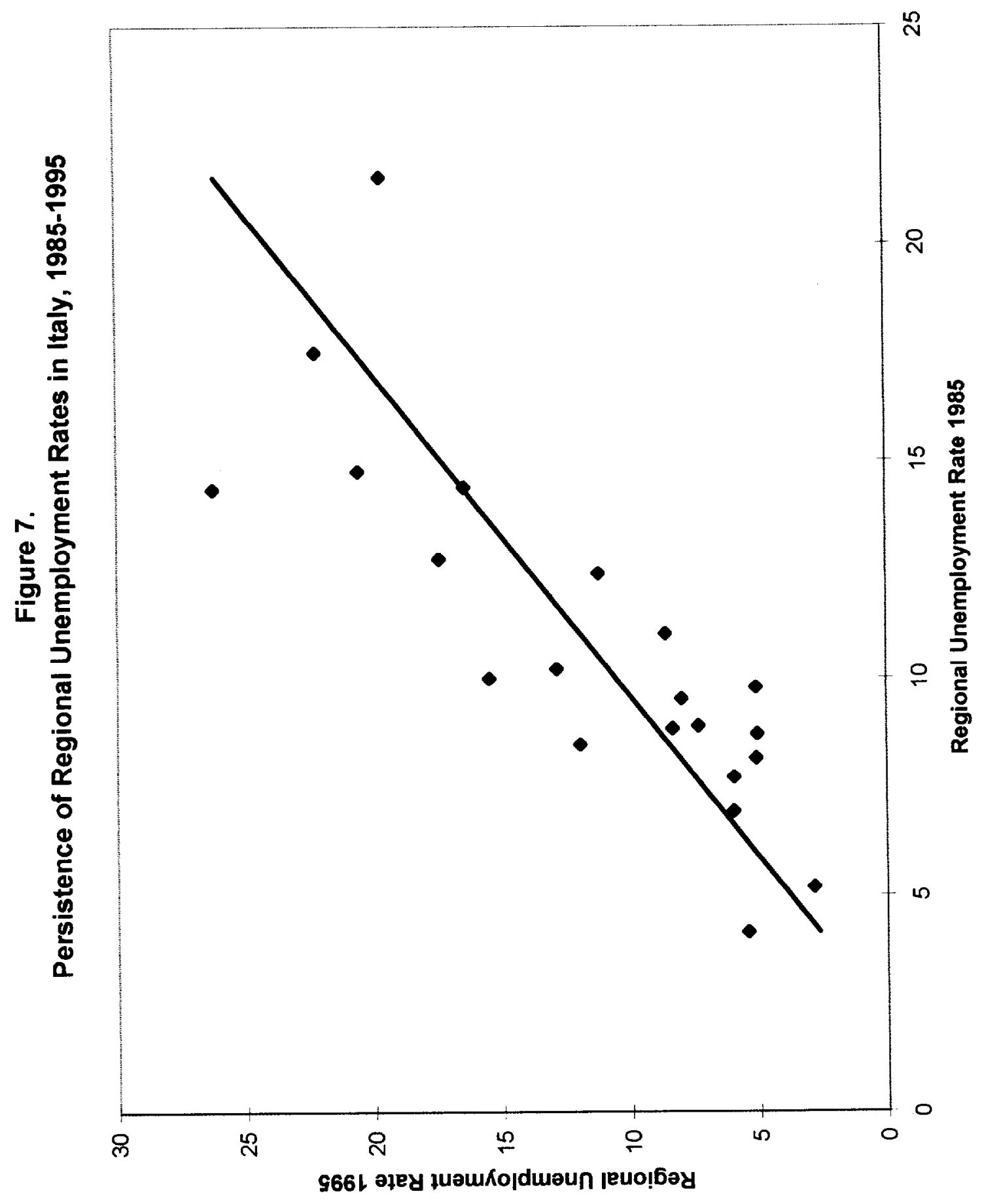




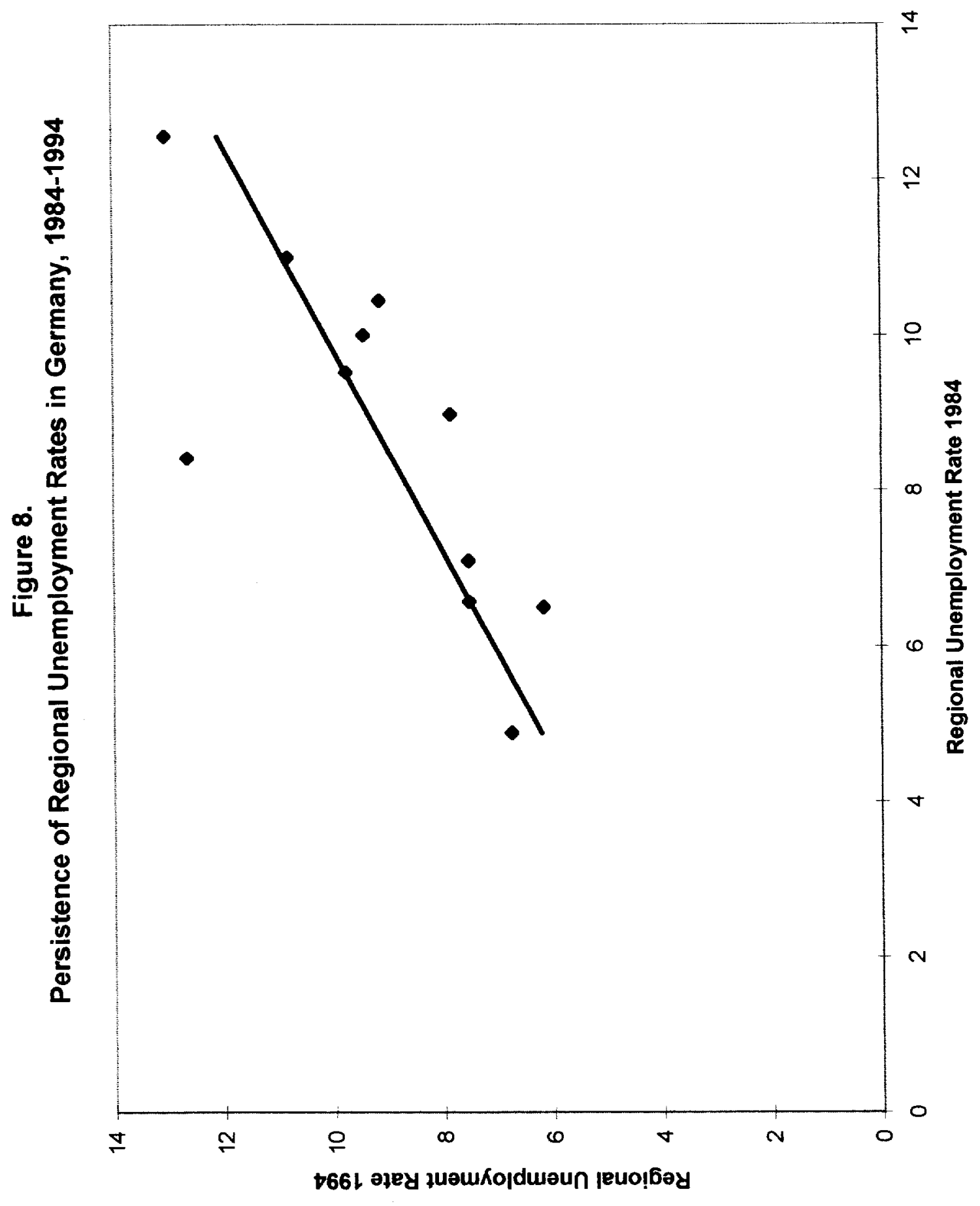




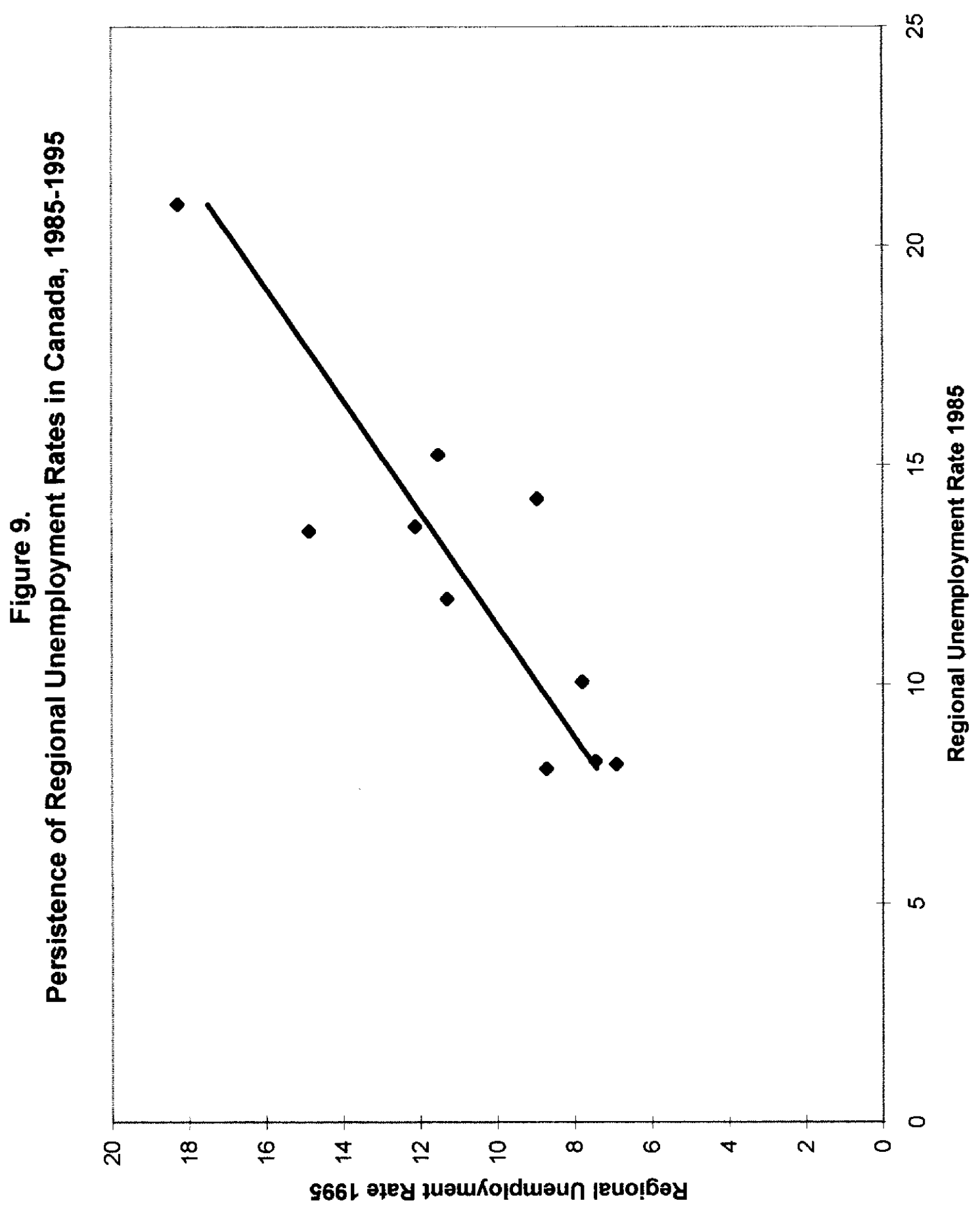




$$
\text { II }
$$




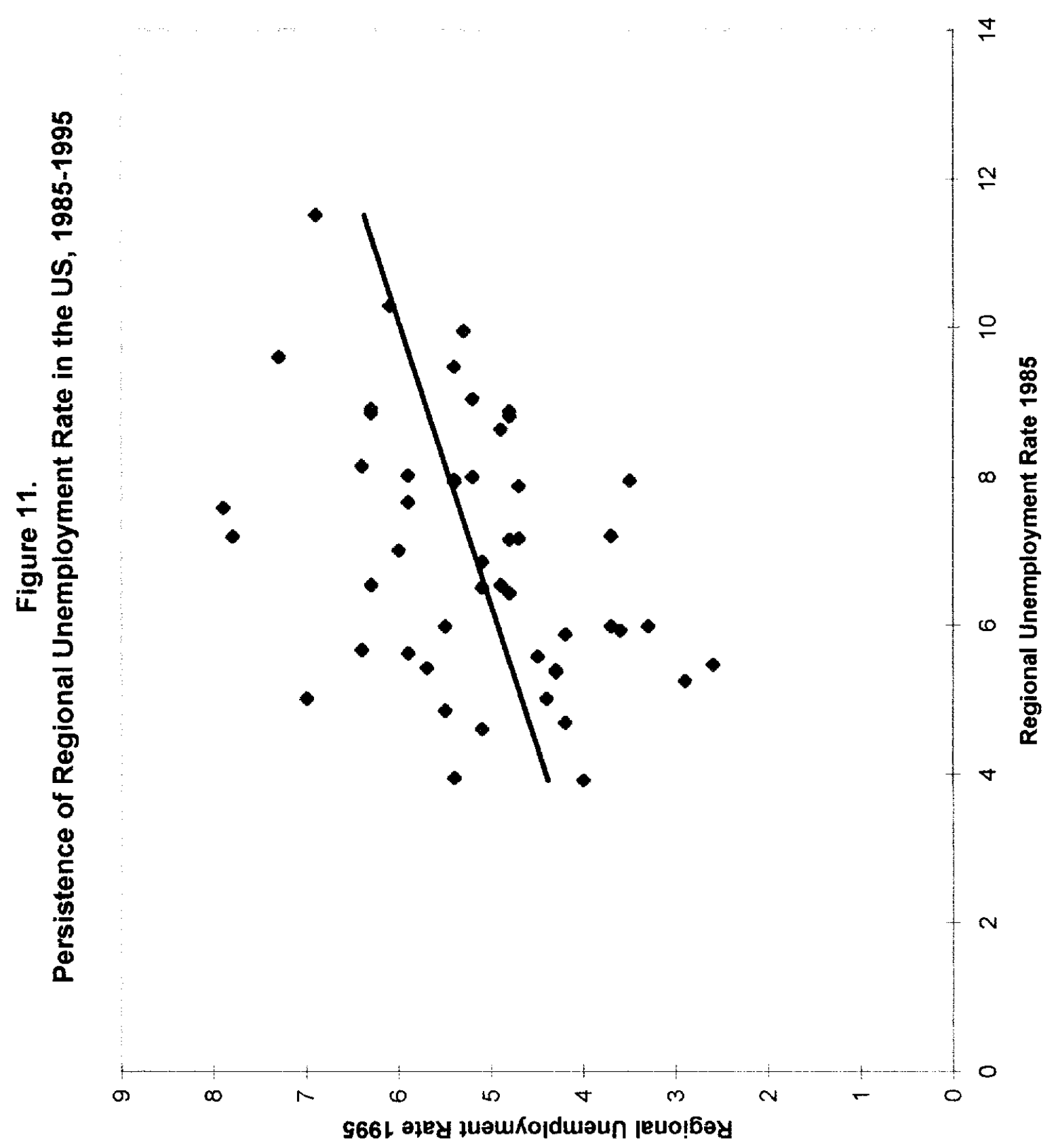


the persistence of unemployment deviations from these regional means. The econometric identification of such deviations, however, requires a specific statistical model. We will argue in the next section that, particularly in Europe, regional shocks with persistent effects play an important role, and that persistence is in part due to a low propensity of workers to migrate away from regions where unemployment exceeds the local natural rate. ${ }^{6}$

According to the model of adjustment sketched at the start of this section, an unemployment rate persistently above the local natural rate should be associated with downward pressure on regional prices. Eventually, increasing local competitiveness will feed through positively to local labor demand. For Canada and Italy, figures 12 and 13 show some negative long-run cross-sectional association between average regional relative inflation (measured by the GDP deflator) and average regional relative unemployment. For Germany, figure 14 shows a positive correlation. Thus, although ongoing unemployment should in theory lead to a regional terms of trade loss over time, the tendency for this to occur in practice is tenuous. (For the UK and US, regional/state price indexes are not available. $)^{7}$

Government fiscal stabilizers deliver transfers to depressed regions; furthermore, national fiscal systems typically redistribute revenue from richer to poorer jurisdictions. Figures 15 and 16 document, for Canada and Italy alike, a significant positive correlation between average regional unemployment and average transfer inflows. Figure 17, for the US, shows a positive but only marginally significant correlation. ${ }^{8}$ These pictures suggest a potentially important role for fiscal transfers in providing insurance against regional recession.

The persistence of transfers mirrors that of unemployment rates. In both Canada and Italy, the ranking of high unemployment regions is remarkably stable over time and correlates well with 


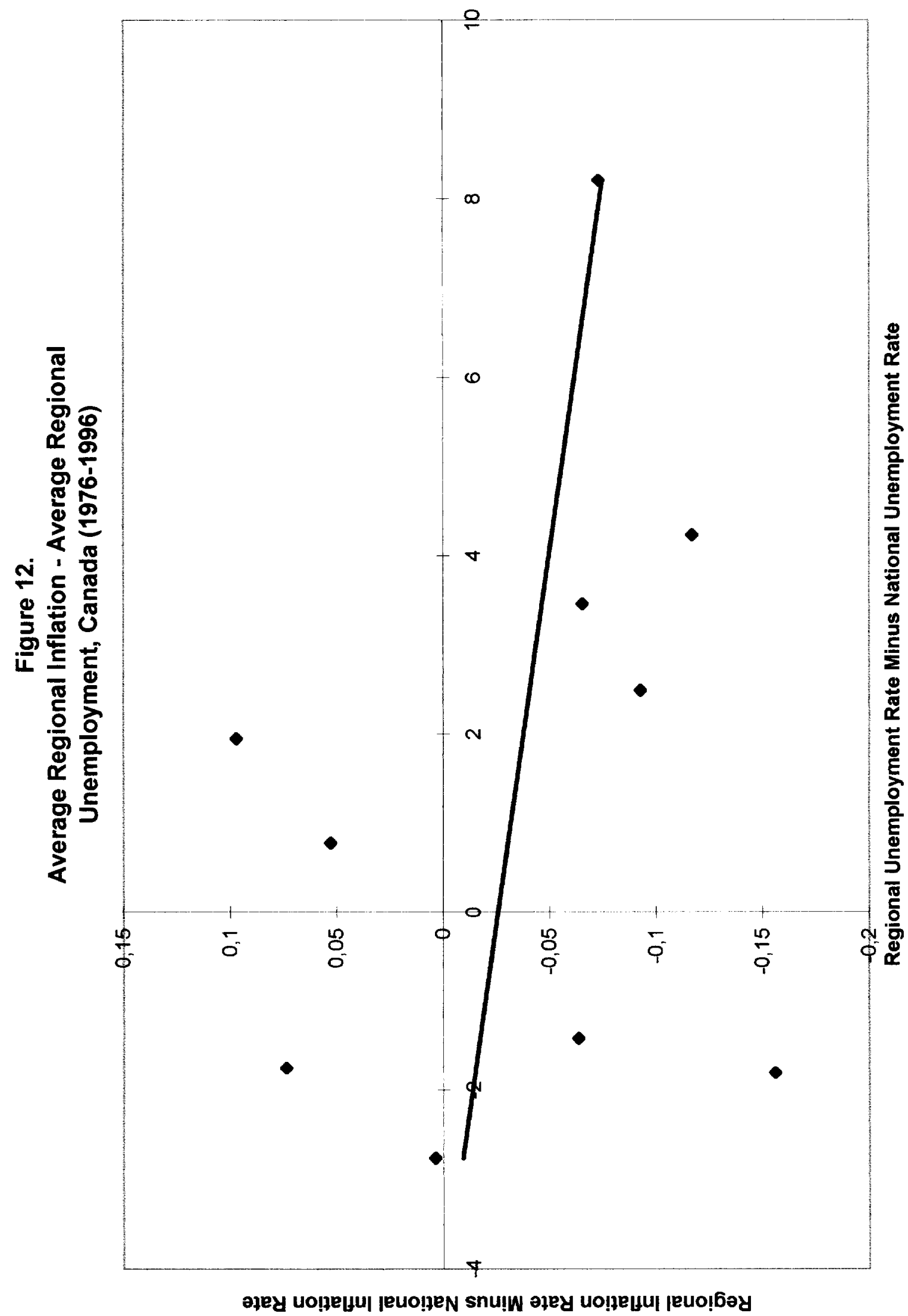




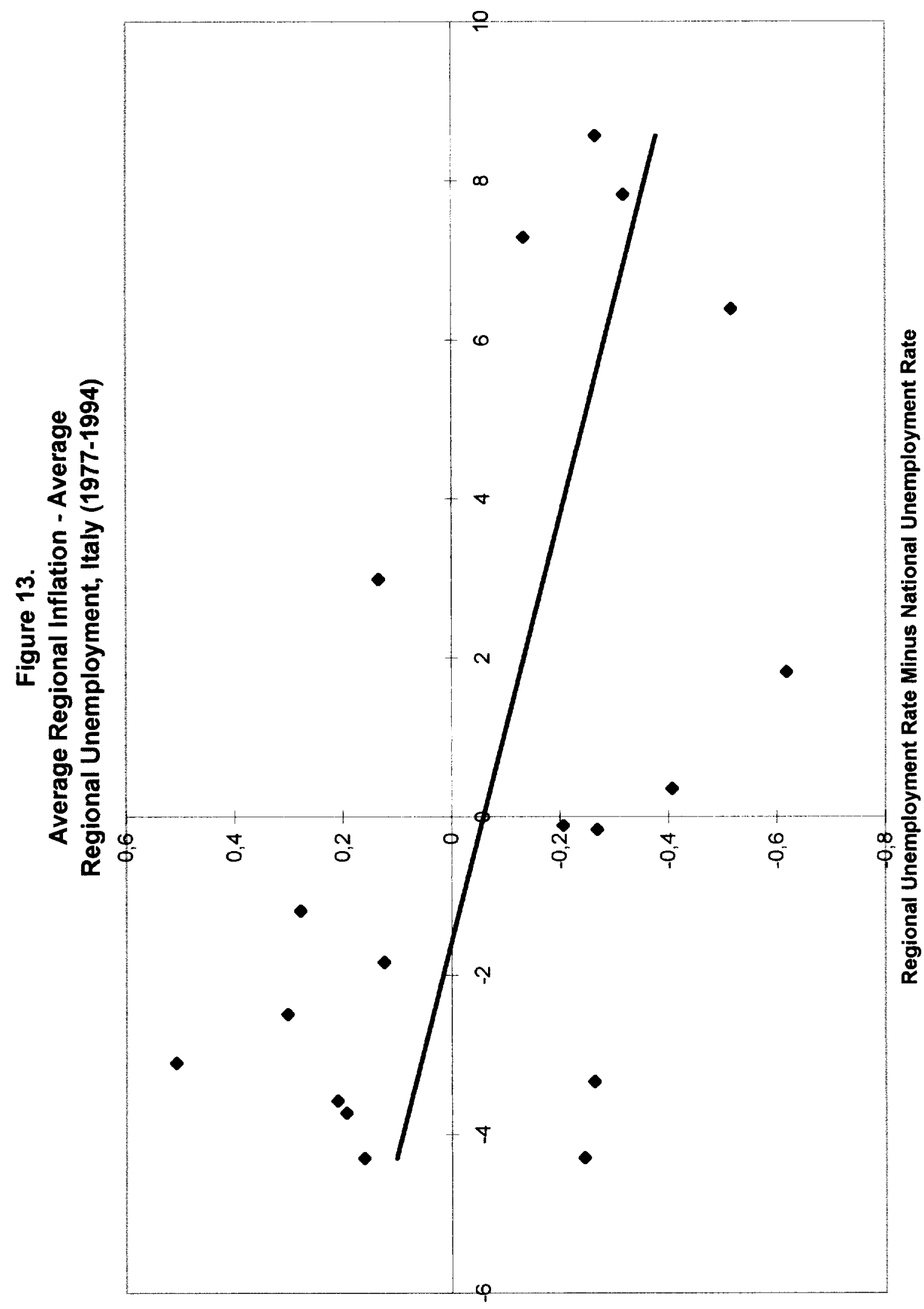

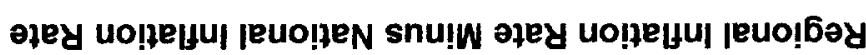




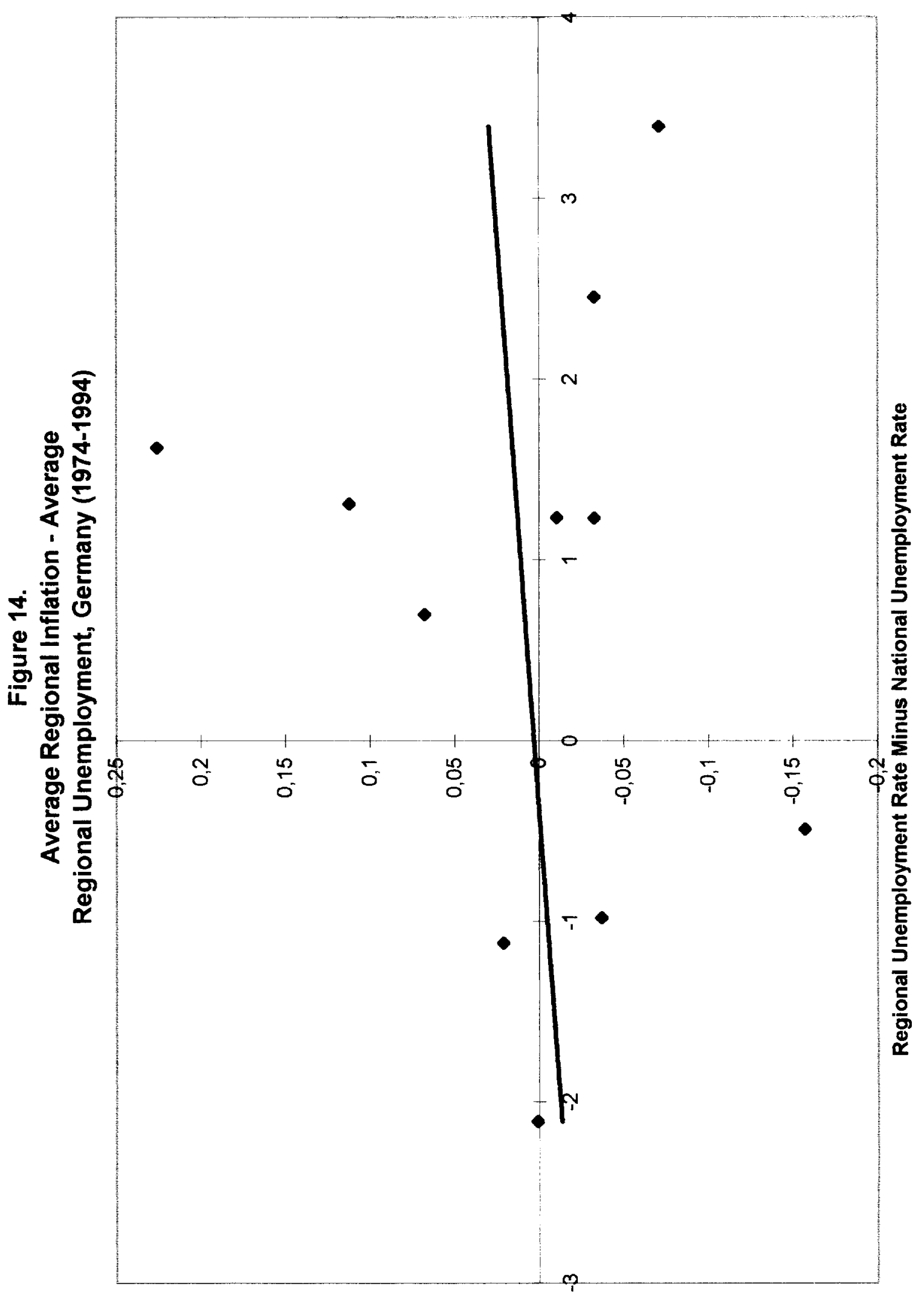

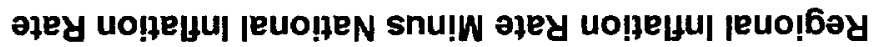




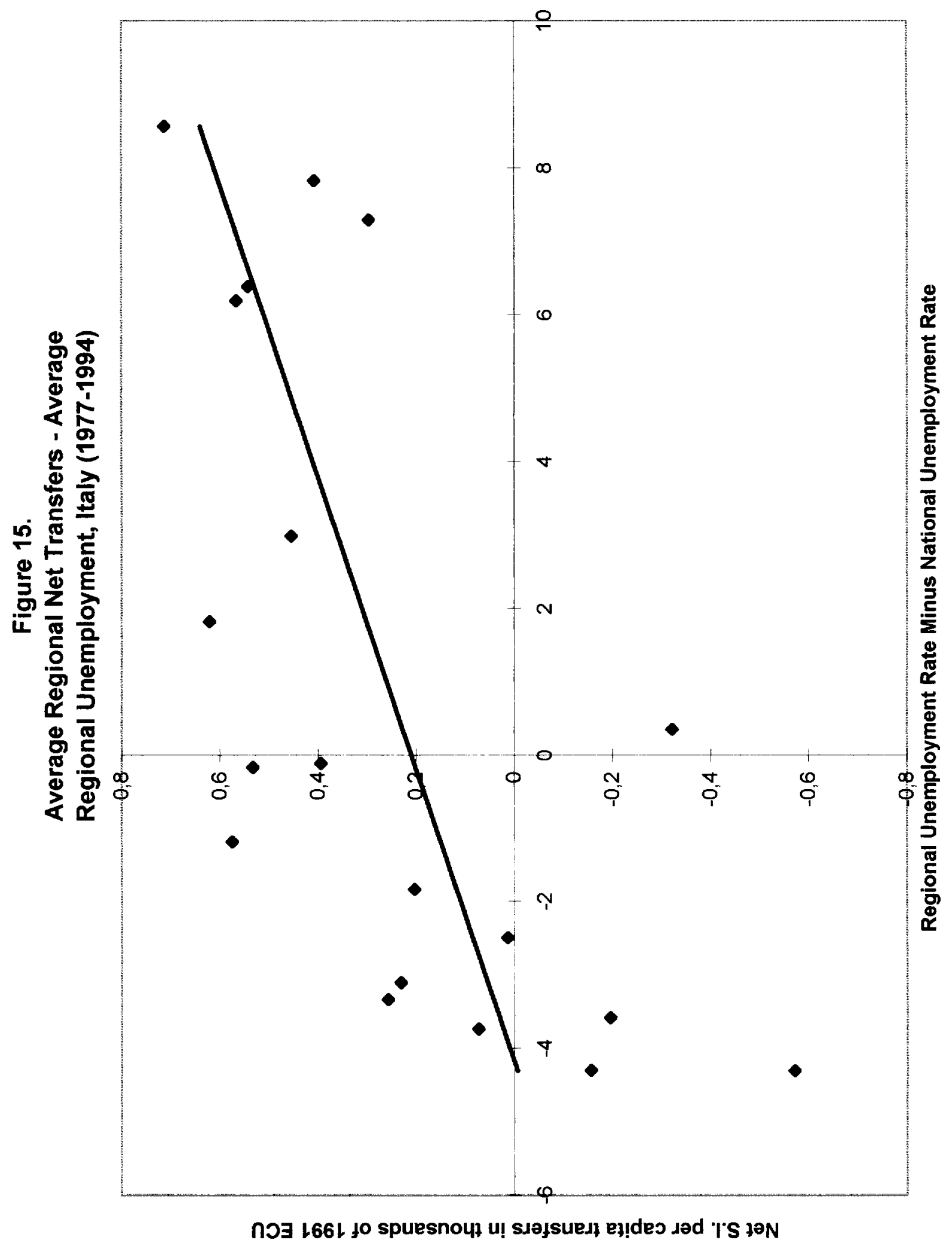




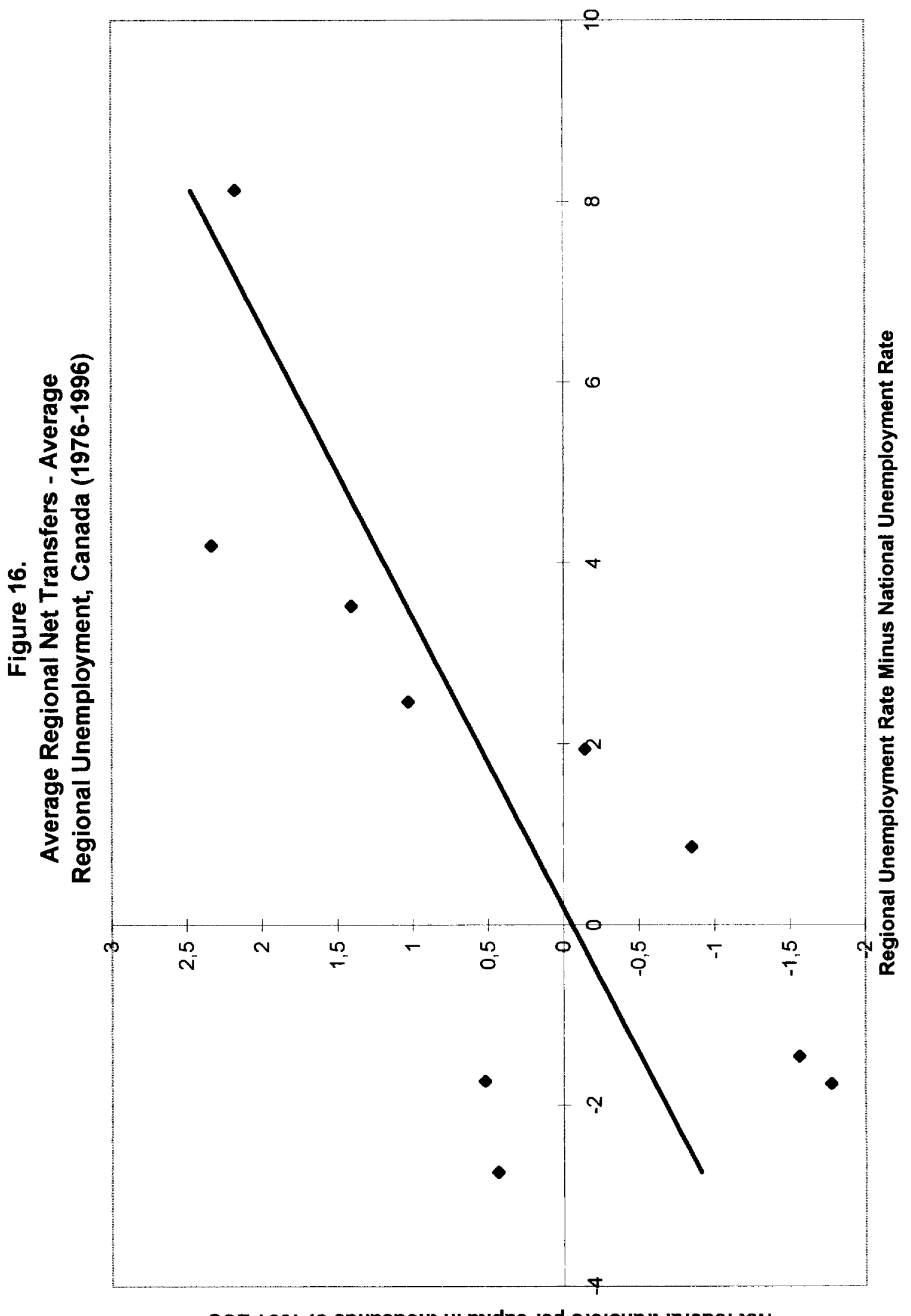

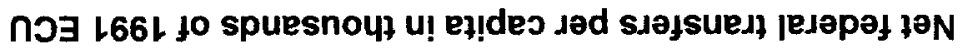




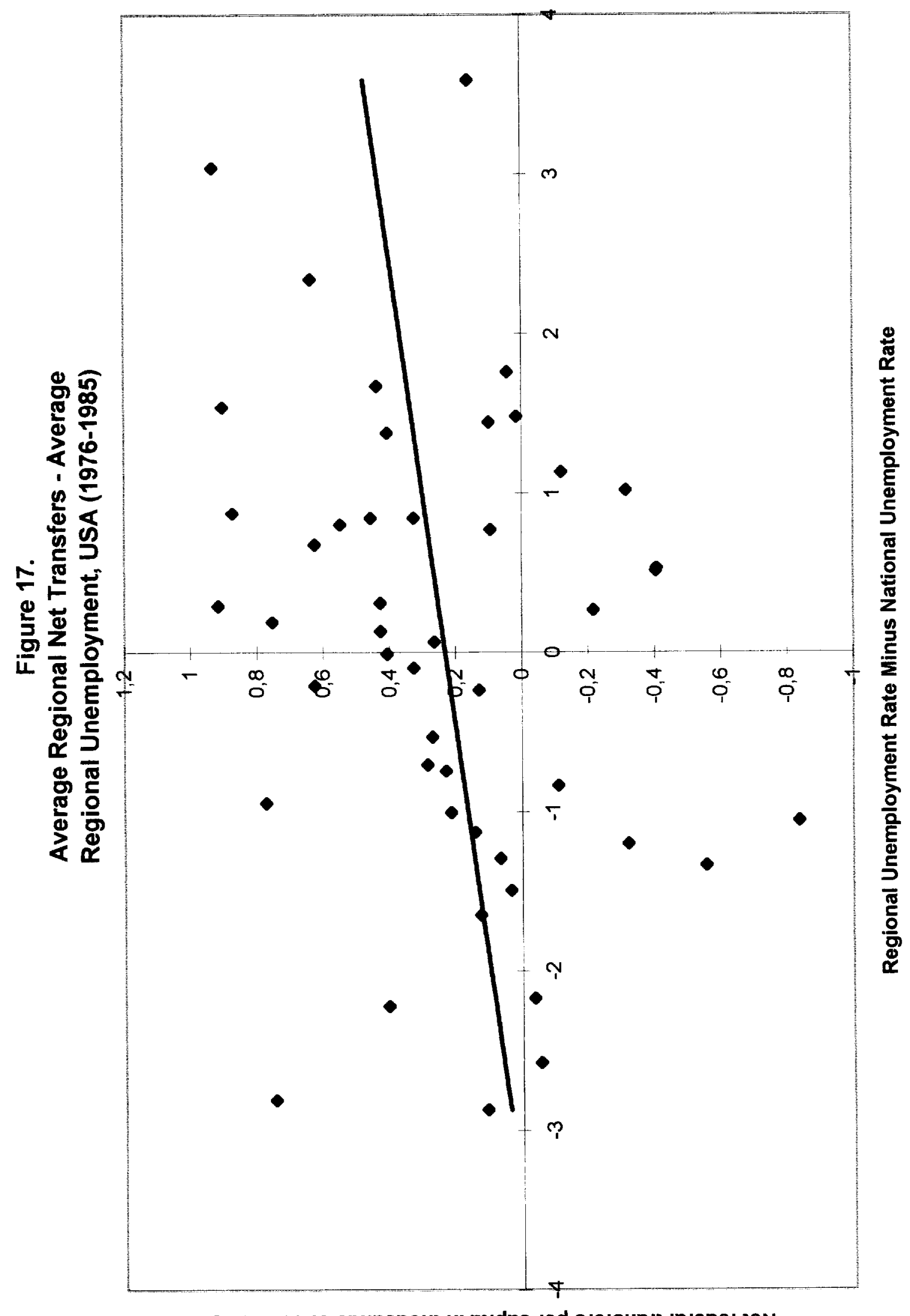

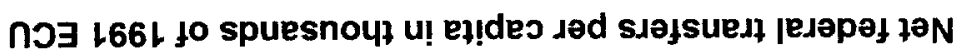


ranking by net transfer inflow per population member. Clearly, intranational fiscal flows to Canada's Atlantic provinces and Italy's Mezzogiorno play a significant redistributive role, and are not merely responding as short-term automatic stabilizers to temporary regional shocks. ${ }^{9}$ Their availability facilitates delayed regional adjustment. An entire national economy could postpone adjustment in the same way only if it could arrange for persistent streams of unrequited transfers from foreigners.

\subsection{Barriers to regional adjustment}

The balance of this paper contains a critical review and synthesis of earlier studies relevant to a study of regional adjustment within existing currency unions. On the basis of that review and some new evidence, we argue that in Europe and to some extent in Canada, adjustment to local employment shocks via domestic migration is more limited than in the US.

In addition, relative regional price adjustments also appear to play a limited role. It could be that interregional real exchange rates are potentially quite flexible, but that in existing currency unions, labor mobility, high interregional trade elasticities, and a paucity of asymmetric real shocks all make for regional relative price stability. To some degree the US fits this picture. We argue that in existing Europcan currency unions, however, interregional real exchange rates are actually rather rigid, and hypothesize that political imperatives underlie the rigidity.

Interregional fiscal transfers, especially long-term redistributive transfers, seem to be used quite heavily in Europe and Canada. Given the absence of prompt and strong internal adjustment mechanisms, fiscal flows therefore appear to play a prominent role--sometimes an uneasy one--in the non-American currency unions. 
Two related conclusions for EMU follow. First, limited market flexibility within EMU countries will make it harder for them to cope with nation-specific shocks, as the latter generally have heterogeneous regional impacts. Second, if EMU aims to attain the degree of economic cohesion of its constituent nations, limitations on national fiscal policies will eventually make it hard to resist the extension of existing EU mechanisms of income redistribution.

\section{Adjustment through migration}

\subsection{Data on migration}

A comparison of labor mobility in the US, Canada, and Europe begins with the raw data on interregional labor movements. The OECD reports that in 1986, 1.1 percent of Britons and Germans changed their region of residence, as opposed to only 0.6 percent of Italians but 1.5 percent of Canadians and 3 percent of Americans (OECD 1990). ${ }^{10}$ These numbers probably understate the Canadian economy's capacity to reallocate labor interregionally, as they do not account for foreign migration, which is substantial for Canada. Canada thus would appear to occupy an intermediate position between the European countries and the US. De Grauwe and Vanhaverbeke (1993) report similar magnitudes for a larger sample of EU countries in 1987, defining a country's mobility index by the regional average of immigration plus emigration as a percent of regional population. Their results indicate lower intranational labor mobility in southern than in northern Europe. While intranational migration is lower in most of Europe than in the US or Canada, international movements of people within Europe are, at present, smaller still.

If the goal is to assess the role of labor migration in reducing large regional employment differentials, net rather than gross migration numbers might be more revealing. Table 1 reports 


\section{Table 1: Average Net Interregional Migration (percent of regional population)}

\begin{tabular}{|c|c|c|c|c|c|}
\hline Period & Canada & US & Germany & Italy & UK \\
\hline $1970-79$ & 0.62 & 1.20 & 0.27 & 0.37 & 0.47 \\
\hline $1980-89$ & 0.63 & 0.84 & 0.34 & 0.33 & 0.26 \\
\hline $1990-95$ & 0.52 & 0.87 & 0.31 & 0.40 & 0.20 \\
\hline
\end{tabular}

National figures are population-weighted averages over regions. For the period indicated, each regional figure is calculated as the average absolute value of the change in regional working-age population (measured net of national working-age population growth). German numbers are for western Länder only, leaving out Berlin.

such numbers for Canada, the US, Germany, Italy, and the UK. Here we approximate net in- or out- migration for a region as the avcrage absolute value of the percentage change in regional working-age population (measured net of the rate of national working-age population growth). National averages are population-weighted averages of the regional growth rates. For Germany our sample consists of ten western Länder, Berlin being the omission.

Subject to the caveat that average regional sizes differ across countries, the general impression that emerges is that net migration is substantially higher in North America than in Europe. If these numbers can be taken as a rough indicator of labor mobility, mobility is higher in Canada than in Europe, and higher still in the United States. Mobility, as measured by net flows, seems on the whole to be similar in Germany, Italy, and the UK. However, a comparison of these numbers with those reported by De Grauwe and Vanhaverbeke (1993) would suggest that 'gross' or two-way labor flows are more important in Germany and the UK than in Italy.

\subsection{Interpreting migration data: low barriers or regionally balanced shocks?}

There is a major conceptual problem in accepting migration data as evidence on mobility. 
Observed net flows reflect the push of asymmetrical shocks as well as the resistance due to migration barriers. Thus, if idiosyncratic regional shocks have not been prominent, then little migration would be observed even with low barriers. As Eichengreen (1991) notes in discussing similar data, "simple tabulations still no not distinguish the disturbance from the response." Indeed, because our basic data all are mostly endogenous economic variables, this identification problem is the central one in reliably assessing regional adjustment patterns. In the present context of migration, the identification problem surfaces in the possibility that labor mobility is (potentially) really quite high even though labor movements are small.

The wide and variable regional unemployment differentials in Europe might be viewed as prima facie evidence of asymmetric localized shocks that should create migratory pressures. Also supportive of the prevalence of such shocks is the finding of De Grauwe and Vanhaverbeke (1993) that over 1976-90, the variability in long-run average regional employment growth rates within European countries tends to exceed that among European countries (with less regional divergence in northern than in southern Europe). But as these authors point out, employment levels and unemployment rates are endogenous variables that respond to policies and may convey little information about the incentives to migrate. For example, more liberal administration of unemployment benefits in a region not only can increase unemployment there, it may even lead to migration of workers into high-unemployment areas, a phenomenon seen in Canada (Courchene 1993, p. 144). It is important to correct for idiosyncrasies in regional institutions or structure in assessing the typical migratory response to a regional shock within a country.

One way to accomplish this end is to postulate a specific statistical model of regional shocks, and to gauge their prevalence econometrically. There have been several attempts along 
these lines. On balance, they point to a potentially important role for asymmetric region-specific disturbances within EU economies. Viñals and Jimeno (1996) estimate a dynamic model of annual regional unemployment in which a region's unemployment rate can be decomposed into a regionspecific constant (the region's 'natural' rate) and regional, national, and EU-wide random components. These components are identified by the assumption that region-specific shocks do not influence the national data-generating process for unemployment and that nation-specific shocks do not influence the EU-wide unemployment process. Thus, the EU unemployment rate is strongly exogenous with respect to individual EU members' unemployment rates, and both EU and national unemployment are strongly exogenous with respect to regional unemployment. Viñals and Jimeno find that for forecast horizons of up to five years, almost two-thirds of the conditional variance of European subnational unemployment rates can be explained by regionspecific factors. ${ }^{11}$

Forni and Reichlin (1997) use a dynamic unobserved index model to separate fluctuations in annual regional growth rates of real output into parts due to EU, national, and regional factors. They find that the decomposition for EU regions is quite similar to that for US states. Although regional shocks are found to play a significant role in Europe, they do not appear as important as in the Viñals-Jimeno analysis of unemployment rates. However, the statistical method of Forni and Reichlin allows the EU-wide component of growth and the national components to have divergent regional effects. They also search for a European 'core', defined as a group of regions in which at least 70 percent of the variance of output growth comes from the common Europewide shock component. The resulting set of regions does not coincide with a group of EU member states, and all major countries are, to some degree, out of the core. Conversely, Spain 
and Italy, which usually are identified as 'peripheral' in studies of EMU as an optimum currency area, have important regions that belong to the core. These findings again suggest the presence of regional asymmetries within EU countries.

\subsection{Structural models of migration response}

The studies just summarized contradict the view that migration barriers within European countries are low and that the low degree of observed migration reflects a scarcity of regionally asymmetric shocks. But even if accepts that asymmetric shocks have occurred, an international comparison of their effects still requires some quantitative standardization of the shocks.

A fairly direct way to compare regional labor mobility across countries is to look at the responsiveness of domestic labor flows to interregional wage differences. Taking this route, Eichengreen (1993a) finds that interregional migration is much more sensitive to lagged changes in wage differentials in the US (1962-88) than in the UK (1961-82) or Italy (1962-85). Lagged unemployment also has the largest estimated effect in the US. ${ }^{12}$

Eichengreen's (1993) estimates constitute strong evidence of relatively limited labor mobility in Europe. However, the current wage difference alone may be an imperfect indicator of the expected lifetime income difference associated with a job change. Furthermore, given the nation-wide wage determination process that prevails throughout much of Europe, regional unemployment differences may find little reflection in regional wage differences. Thus, an alternative framework capturing the dynamic response of regional labor markets to local shocks is a useful complement to Eichengreen's findings.

Such an empirical framework was originated and applied to US states by Blanchard and 
Katz (1992). Decressin and Fatás (1995) have explored the implications for regions within Europe. Blanchard and Katz proceed by estimating a three equation vector-autoregressive (VAR) system in which the variables of interest are the change in the log level of regional employment, the log employment rate (ratio of employment to labor force), and the log participation rate (ratio of labor force to working-age population)--all variables being expressed as deviations from respective national means. The motivation for focusing on the change in the employment level is that the variable appears to have a unit root component, that is, a random component subject to permanent changes. This result for the US, which generalizes to European countries as Decressin and Fatás (1995) illustrate, is itself suggestive that permanent (or at least highly persistent) regional shocks are regular occurrences in industrial countries.

In each of Blanchard and Katz's three regression equations, the left-hand variable depends on its own lags and those of the other two variables, as well as a random disturbance. In addition, while the change in employment depends only on lagged variables, the employment and participation rates depend on the current change in employment. This feature reflects Blanchard and Katz's critical identifying assumption that innovations in the employment-change equation are exogenous labor-demand shocks, which affect the other two variables contemporaneously with no immediate reverse feedback. If one buys the identifying assumption, the estimated dynamic system allows one to trace through time the responses of all three variables to an asymmetric regional labor-demand shock. ${ }^{13}$ One can also track the effect on migration from the region. Note the identity that regional employment, $N$, equals the product of the employment rate, $E$ ( 1 minus the unemployment rate), the participation rate, $P$, and working-age population, Pop: 


$$
N=(E)(P)(P o p)
$$

In terms of logarithmic changes (which approximate percentage changes), the preceding relationship equates the percent change in total employment to the sum of the corresponding percent changes in the employment rate, the participation rate, and population:

$$
\frac{\Delta N}{N}=\frac{\Delta E}{E}+\frac{\Delta P}{P}+\frac{\Delta P o p}{P o p}
$$

Since our variables are expressed as deviations from national averages, $\triangle P o p / P o p$ can be interpreted as inward migration provided regional demographic trends are shared by the entire nation, or if those trends evolve independently of labor-demand shocks. In that case migration can be inferred from the behavior of employment, the employment rate, and the participation rate.

The other key assumption Blanchard and Katz make is that region-specific characteristics creating mean differentials in labor-market variables can be modeled as region-specific constants in the regression equations. To estimate, they pool their data over all US states, thus allowing regional fixed effects to differ but imposing uniform dynamics. Blanchard and Katz thus address the econometric identification problem by identifying regional labor demand shocks as the estimated residuals from relative employment growth equations that assume fixed but possibly distinct unconditional regional mean growth rates. ${ }^{14}$

Table 2 shows the reactions of the key regional labor-market variables to a one percent positive shock to relative labor demand. The impulse response profiles are based on estimation and simulation of Blanchard-Katz VARs, assuming two lags of each variable. (A variable's impulse response profile simply tracks through time the dynamic effect on the variable of the one 
percent shock to employment.) We have updated the original Blanchard-Katz US data sample to extend it over 1976-95 (their data ended in 1990). We also report estimates for Canada (197696), Italy (1969-95), Germany (1970-93), and the UK (1969-94). For Germany we omit West Berlin: only partial data are available and the city appears to be an outlier in terms of its labormarket behavior.

While the table offers a rich diversity in responses, a few regularities stand out. Perhaps the most salient feature is the much lower persistence of the employment rate effect in the US and Canada compared with the three EU countries. Five years out the employment rate has returned to its initial level in the US and Canada, while in Europe the half-life of the employment rate response is on the order of four to seven years. Part of the answer can be found in migration. In the US there is a substantial initial migratory inflow to the region, which grows, peaks, and then reverses but remains substantial in the long run. In Canada initial migration is smaller, but it then follows a pattern similar to that in the US (albeit with consistently lower migratory flows).

In Italy, in contrast, the adjustment pattern suggests that worker mobility is on the average fairly low, but that there is a part of the labor force (young, skilled, educated workers, and those who live within commuting distance of other 'regions') that is rather mobile and thus in a position to respond rapidly to shocks. After these workers have reacted, others find it more difficult to move, even if they experience a long unemployment spell or ultimately move out of the labor force. The very persistent participation changes for Italy (and some other countries) could reflect changes in disability status, early retirements, and movement between the legitimate and underground economies. In 1993, only 32.9 percent of Italian men aged 55 to 64 were officially participating in the labor force. (The comparable participation rates were about twice as high in 


\begin{tabular}{|c|c|c|c|c|c|}
\hline Country & Variable & First year & Five years & Ten years & Fifteen years \\
\hline \multirow[t]{4}{*}{ Italy } & Employment & 1.00 & 0.69 & 0.55 & 0.45 \\
\hline & Employment rate & 0.23 & 0.12 & 0.07 & 0.04 \\
\hline & Participation rate & 0.56 & 0.36 & 0.24 & 0.15 \\
\hline & Migration & 0.22 & 0.21 & 0.24 & 0.27 \\
\hline \multirow[t]{4}{*}{ Germany } & Employment & 1.00 & 1.03 & 0.57 & 0.17 \\
\hline & Employment rate & 0.28 & 0.49 & 0.10 & -0.02 \\
\hline & Participation rate & 0.61 & 0.23 & 0.34 & 0.20 \\
\hline & Migration & 0.11 & 0.31 & 0.13 & -0.01 \\
\hline \multirow[t]{4}{*}{ UK } & Employment & 1.00 & 0.63 & 0.37 & 0.36 \\
\hline & Employment rate & 0.11 & 0.04 & -0.04 & -0.02 \\
\hline & Participation rate & 0.85 & 0.42 & 0.14 & 0.04 \\
\hline & Migration & 0.04 & 0.17 & 0.28 & 0.33 \\
\hline \multirow[t]{4}{*}{ Canada } & Employment & 1.00 & 0.63 & 0.37 & 0.34 \\
\hline & Employment rate & 0.46 & -0.05 & -0.12 & -0.08 \\
\hline & Participation rate & 0.43 & 0.25 & 0.12 & 0.09 \\
\hline & Migration & 0.11 & 0.43 & 0.37 & 0.32 \\
\hline \multirow[t]{4}{*}{ US } & Employment & 1.00 & 0.74 & 0.44 & 0.48 \\
\hline & Employment rate & 0.24 & -0.01 & -0.03 & 0.00 \\
\hline & Participation rate & 0.43 & 0.16 & -0.02 & -0.01 \\
\hline & Migration & 0.33 & 0.59 & 0.49 & 0.49 \\
\hline
\end{tabular}


the US and UK, and roughly 85 percent in Japan and Switzerland).

Like Italy, Germany displays a small initial migration response and a large initial participation response. Migration subsequently grows but then reverses direction, because the long-run permanent component of the labor-demand shock is small. In the UK, the participation response is an even more dominant equilibration mechanism, with migration appearing to gain in importance only in the very long run.

Two caveats are important in interpreting these long-run results. First, by modeling the participation and employment rates as stationary or mean-reverting rather than unit root processes, the statistical model forces migration to accommodate in full permanent changes in the level of employment. Second, the data series are too short to provide any reliable information about long-run responses. Thus, no long-run predictions of the model can be taken too seriously. The question, really, is whether the modeling assumptions we have made seriously distort estimates of short- and medium-term responses. We therefore estimated a version of the model in which relative employment is stationary, experiencing exclusively temporary fluctuations around a deterministic time trend. Necessarily in this alternative model, the long-run effects of labordemand shocks on migration is zero. However, the first year effects and the response five years out are very close to those reported in table 2 .

Decressin and Fatás (1995) apply the Blanchard-Katz methodology (over the years 197587) to European countries and to a pooled sample of European subnational regions and small countries. As above, they find large initial participation effects. They also find that migration, while quite low in the short run, rises in the long-run to accommodate a fairly large estimated permanent component of the typical employment shock. Most importantly, their results differ 
from ours in finding that European employment rate responses are not noticeably more persistent than in the United States. We have already described why the long-run implications of these models should be discounted. We are less certain why Decressin and Fatás find such low employment rate persistence. The discrepancy seems to result from their identification of regionspecific variables, not as simple differences from national averages, but as residuals from a regression of the log regional variable on the log national average. Blanchard and Katz (1992) found that using this approach instead of simple differences matters little for the US. We have found that the choice has only minor effects on the Canadian and UK results. But when one applies the 'residual' approach to Germany and Italy, the employment rate response indeed appears much less persistent.

We are unpersuaded that the method used by Decressin and Fatás yields an economically meaningful representation of the region-specific component of shocks. The justification for using their method to identify idiosyncratic regional shocks is, presumably, that for each region, the estimated time series of shocks is uncorrelated with the time series of the corresponding nationalaverage variable. But this property is not clearly desirable or reasonable. As the study by Eichengreen (1993a) illustrates, region-specific shocks may be correlated with aggregate unemployment because they are generated by events--real exchange rate shifts, oil shocks, increased competition from low-wage countries--with divergent impacts on different regions; see also Davis, Loungani, and Mahidhara (1997). Furthermore, common shocks may feed into unemployment through distinct regional persistence mechanisms, as in the statistical model of Forni and Reichlin (1997). Our analysis, instead, embodies the simple hypothesis that any gap between the regional unemployment rate and its natural level should set in train pressures for 
migration. On this assumption, regional labor-demand shocks would seem to have much more persistent effects in Europe than in North America. This finding, consistent with the other evidence, suggests that there is indeed substantially lower labor mobility, not just among, but within the existing currency unions of Europe.

It is tempting to relate the different unemployment adjustment patterns to differing labormarket institutions, but this is not straightforward. Germany has more open-ended unemployment benefits than Canada or the US, and a higher benefit replacement rate than either of those countries or the UK (Nickell 1997 presents a convenient OECD comparison; see also Bertola and Ichino 1995). However, Italy's official u.i. entitlement is very modest, and Canada's system can easily be 'worked' to allow a high level of income support punctuated only by a short spell of employment each year (Courchene 1993; Green and Riddell 1997). Although unemployment benefits may be paid in disguised forms in Italy (e.g., medical benefits), generous jobless provisions seem at best only part of the reason for persistent regional unemployment. Other factors relevant particularly to continental Europe may be the very high coverage of wages by union contracts, a factor inhibiting regional wage flexibility, and relatively high tax rates, which discourage job creation, increase 'wait' unemployment, and make underground activities more attractive. A definitive explanation of sluggish labor reallocation must rest on further microeconometric evidence.

Housing markets are very likely to be part of the story, however. Hughes and McCormick (1987) explain how rent controls, publicly allocated rental housing, and subsidized owner occupation restricted the stock of private rental housing in the UK, reducing mobility and raising aggregate unemployment. Oswald (1996) demonstrates a negative relationship between the 
private rental housing stock and unemployment for OECD countries. The US has low unemployment despite a high rate of home ownership, but US markets for long-term mortgages are relatively efficient and overall transaction costs low.

\section{Regional relative price adjustment}

Research on the developed currency unions of North America and Europe suggests that, on almost any measure, relative regional prices tend to fluctuate less than international relative prices (Vaubel 1976, 1978; Eichengreen 1991; De Grauwe and Vanhaverbeke 1993; von Hagen and Neumann 1994). This fall in relative price variability is often viewed as one of the advantages of a currency union. At the same time, it raises questions about how the intranational mechanism of adjustment to permanent shocks differs from the international mechanism. ${ }^{15} \quad$ For Canada, Germany, and Italy, table 3 shows standard deviations of $(\log )$ regional GDP deflators relative to national GDP deflators. Table 4 does an analogous calculation of the standard deviation of annual first differences in such real exchange rates. Table 3 is meant to illustrate the long-run range of variation in real exchange rates that these currency unions have experienced over a quarter century, while table 4 is meant to illustrate the degree of short-run (year-to-year) variability in real exchange rates around their trends (which are small in these regional data) ${ }^{16}$

Table 5 (on 1988-1996 national real exchange rate levels vis-à-vis Germany) and table 6 (on changes over that same period) allow a comparison of intranational with international variability in relative prices. Real exchange rate variation within currency unions often is quite low 


\begin{tabular}{|c|c|c|c|c|}
\hline Country & Period & Average & High Region & Low Region \\
\hline Canada & $1970-95$ & 1.4 & 2.1 & 0.6 \\
\hline Germany & $1970-95$ & 1.2 & 3.0 & 0.3 \\
\hline Italy & $1970-96$ & 2.5 & 5.0 & 1.0 \\
\hline \multicolumn{5}{|c|}{$\begin{array}{l}\text { Regional standard deviations of the log regional GDP deflator less the log national GDP } \\
\text { deflator. Regional figures are averaged (with equal weights) to obtain each country's } \\
\text { aggregate regional variability measure. }\end{array}$} \\
\hline
\end{tabular}

\begin{tabular}{|l|c|c|c|c|}
\hline \multicolumn{5}{|l|}{ Table 4: Intranational Relative Price Variability: Annual Changes (percent) } \\
\hline Country & Period & Average & High Region & Low Region \\
\hline Canada & $1970-95$ & 0.8 & 1.1 & 0.3 \\
\hline Germany & $1970-95$ & 0.9 & 1.2 & 0.3 \\
\hline Italy & $1970-96$ & 0.8 & 1.2 & 0.6 \\
\hline $\begin{array}{l}\text { Regional standard deviations of regional GDP deflator inflation rate less national } \\
\text { GDP deflator inflation rate. Regional figures are averaged (with equal weights) to } \\
\text { obtain each country's aggregate regional variability measure. }\end{array}$
\end{tabular}



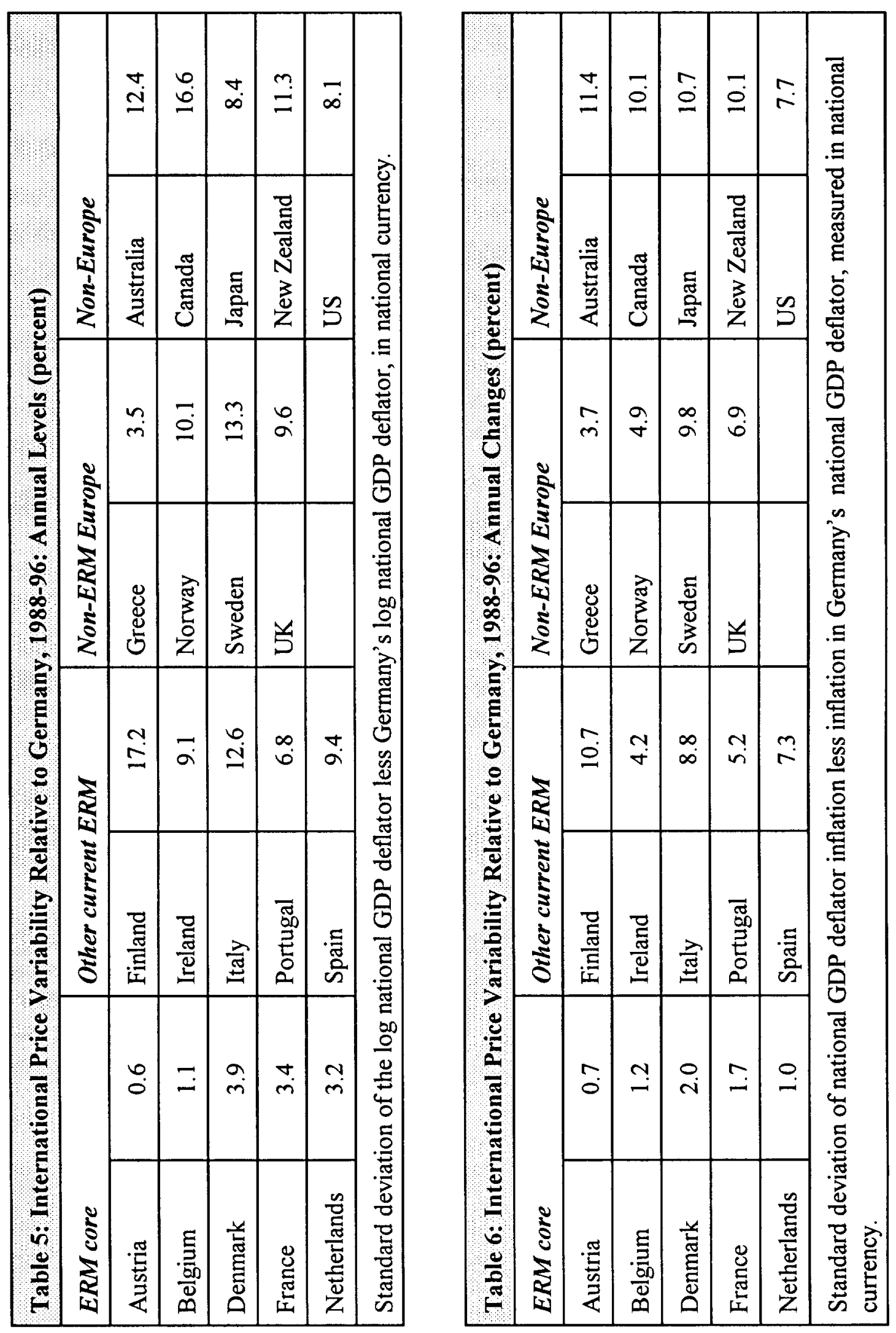
compared to that between countries, as previous research has shown. With more of the European Exchange Rate Mechanism's (ERM) track record available, however, it is clear that fixed exchange rates can induce international real exchange rate volatility levels matching those seen across regions of low-inflation countries. Of Germany's five 'ERM core' partners--those that have not realigned against Germany in the last ten years--all with the possible exceptions of Denmark and France show real exchange rate variability that is closely consistent with that within the three currency unions. Austria, indeed, shows less variability on either measure than the average German Land.

Outside the ERM core, real exchange rate volatility is much higher, but to differing degrees. In this respect there is little difference, on the whole, between the non-core ERM members, which have realigned or floated against Germany in the 1990s, and European countries outside the ERM, which have at times shadowed the DM or ECU. Finland and Sweden, both reliant on primary product exports, stand out for their wide real exchange rate swings. Greece's low real-rate volatility is remarkable; evidently changes in the drachma's nominal rate have largely offset differential inflation. Real exchange rate variability against Germany tends to rise outside Europe, but in this respect the US record differs little from that of most other countries likely to enter EMU in 1999.

For Vaubel $(1976,1978)$, the amplitude and frequency of real exchange rate movements between two regions is almost a sufficient statistic of their suitability to form a currency union. An absence of asymmetric real shocks, interregional factor mobility, regional proximity, and a high extent of mutual trade all should promote stability in the real exchange rate. Vaubel and the authors who have followed him all recognize that the observed volatility of international real 
exchange rates may well overstate the macroeconomic disadvantages of forming a currency union. Particularly under floating nominal exchange rates, monetary and portfolio shocks that would be absent in a currency union contribute powerfully to real exchange rate volatility. ${ }^{17}$

The opposite possibility has received less recognition, however. Market distortions and government policies may allow too little real exchange rate variation in a currency union, given the asymmetric shocks that occur. On this reading, the stability of interregional real exchange rates could reflect systematic interference with the workings of markets, motivated by distributional or political ends, and reveal little about a currency union's innate desirability.

For Europe, the latter possibility derives credence from the existence of nation-wide wage norms and the practice of administered pricing in many sectors, including housing. Thus, the authors of 'One Market, One Money' express the hope that under the single currency, competition and wage discipline will enhance price and wage flexibility, facilitating intra-EMU real exchange rate adjustment in the absence of significant international labor mobility (Emerson et al. 1992, p. 136). On this view, EMU optimists should wish to see more real exchange rate flexibility between the ERM core and Germany than among German regions (see tables 3-6), but there is scant evidence of this. The effect should be all the more pronounced because an internationally asymmetric permanent shock gives rise to a permanent real exchange rate change, whereas the corresponding disturbance should have only a temporary real exchange rate effect within an area of free factor mobility. The counter-argument, that there have been no asymmetric shocks, rings rather hollow given that the sample underlying tables 5 and 6 includes German reunification. (More formal evidence on the existence of asymmetric national shocks is discussed by Bayoumi and Eichengreen 1996, Forni and Reichlin 1997, Viñals and Jimeno 1996, and 
Weber 1997.)

For the United States, Blanchard and Katz (1992) find that regional relative wage and price movements play at best a small supporting role in the adjustment to permanent labordemand shocks. They ascribe this finding to the predominance of migration as a regional adjustment mechanism in the US. In light of the last section's finding that interregional migration is of more limited importance in Canada and especially in Europe, one might expect to find regional prices playing a bigger role in offsetting regional shocks. Figures $12-14$ suggest that any such tendencies may be small, but these figures do not indicate whether high regional unemployment rates are due to shocks that might warrant price adjustment. ${ }^{18}$ To focus on that issue, we attempt to estimate local price responses conditional on asymmetric shocks to employment.

We do this by estimating bivariate VARs in relative regional employment growth and the $(\log )$ relative regional GDP deflator. This specification imposes the assumption that relative regional employment is subject to permanent shocks, while relative regional prices are not. Eventually, factor inflows within a national economy should eliminate regional price discrepancies due to relative labor-demand shocks, even when those shocks have permanent components.

As in the last section, we impose a common propagation mechanism on all regions in a country but allow for region-specific unconditional mean levels of employment growth and the price of GDP. Our estimated impulse responses incorporate the maintained identifying assumption that employment-growth shocks are labor-demand shifts which can affect local prices within a year, but which themselves respond to local prices only after a year has passed. Again, the German results are based on the ten western German Länder excluding Berlin. 


\begin{tabular}{|c|c|c|c|c|c|}
\hline Country & Variable & First year & Five years & Ten years & Fifteen years \\
\hline \multirow[t]{2}{*}{ Italy } & Employment & 1.00 & 0.80 & 0.79 & 0.79 \\
\hline & GDP deflator & 0.02 & 0.00 & 0.00 & 0.00 \\
\hline \multirow[t]{2}{*}{ Germany } & Employment & 1.00 & 1.50 & 1.53 & 1.53 \\
\hline & GDP deflator & 0.30 & 0.08 & 0.00 & 0.00 \\
\hline \multirow[t]{2}{*}{ Canada } & Employment & 1.00 & 1.25 & 1.22 & 1.22 \\
\hline & GDP deflator & 0.06 & 0.21 & 0.07 & 0.02 \\
\hline
\end{tabular}

Table 7 reports our findings. Only in Germany is their a noticeable short-run local price increase in response to a positive labor-demand shock, and the effect disappears (indeed, becomes slightly negative) immediately after the period of the shock. This pattern provides very weak support for the idea that in Germany local prices help in regional adjustment, since in that country the employment rate remains high long after the initial year of a labor-demand shock (recall table 2). In Canada local prices eventually show a small tendency to rise after the first period, whereas in Italy they don't seem to move at all. The results for Canada change very little when Alberta and Saskatchewan, both big primary commodity producers, are excluded.

The estimates in table 7 imply larger permanent effects of employment shocks than those in table 2, which are based on a VAR including the participation and employment rates. This discrepancy is puzzling. When we add prices to the larger VAR system underlying table 2, however, the implications for regional real exchange rates are close to those of table $7 .^{19}$ 
While the low responsiveness of prices could in principle reflect rapid migratory responses or high interregional trade integration, neither explanation seems plausible for Europe in view of the low migration responses and persistent employment-rate effects documented in the section 3 .

The analysis thus does not contradict the view that interregional real exchange rate variability is relatively low in Europe in part because of price rigidities and government policies that slow the pace of adjustment. This conclusion is neither surprising nor novel. Governments routinely interfere with the income redistributions relative price changes otherwise would cause-the Common Agricultural Policy and the contorted compensation devices that have supported it being one extreme example. Continental European wage-setting institutions by and large also reflect a philosophy of regional equalization in earnings. It is often argued that intra-EU exchange flexibility is incompatible with the survival of the single market, since currency-induced real exchange rate movements would induce strong pressures for protection (see, for example, Eichengreen 1993b). The same argument suggests, however, that large swings in relative regional prices could be politically problematic for economic integration at the national level. Even when domestic labor mobility is low, sharp regional price swings therefore are unlikely to be allowed a big role in adjustment. When interpreted in this light, the low extent of interregional price movement tells us little about the ease with which resources are reallocated in currency unions, or about the need for reallocation.

\section{Interregional insurance and fiscal transfers}

Private insurance markets and government interregional transfer schemes can cushion the effects of temporary and permanent economic shocks. In the case of temporary shocks, they provide 
more complete protection than borrowing would. In the case of permanent shocks they reduce the need for a long-run adjustment in regional consumption levels. A key facet of a currency union's performance depends on how well private or public insurance can fulfill these roles. In this section we compare the roles of private insurance for US states and for EU countries, and then examine the operation of public interregional transfer systems in the US, Canada, and Europe. A major finding is that transfers are quite persistent, reflecting the persistence of unemployment, and thus facilitate slower regional adjustment.

\subsection{Evidence on private insurance}

Some basic evidence on the mechanism of private insurance within currency unions has been developed by Atkeson and Bayoumi (1993), who compare the extent of private risk sharing across US census regions with that across European countries. A starting point for comparison is the relation of gross regional product to personal income, the difference between the two consisting of external capital income, remittances of labor earnings, and government transfers. Even excluding government and labor transfers, the percentage by which GDP differs from personal income in US census regions is one to two orders of magnitude above the percent difference between French, German, or Italian GDP and GNP. Thus, New England's personal income exceeded its GDP by around nine percent on average over 1963-86, whereas the corresponding figure for Germany or France is only one-fifth of a percent.

Atkeson and Bayoumi also found (in 1966-86 data) that US national capital income is the preponderant determinant of US regional capital income, and that US regional capital income is slightly (but significantly) negatively correlated with regional labor income, suggesting some role 
of financial wealth in insuring human wealth, albeit a small one. The situation appeared to be quite different in the European Community on 1970-87 data. Capital incomes in Belgium, France, Greece, the Netherlands, and the UK appeared more weakly correlated with the aggregate capital income of those countries plus Germany. In a more recent study covering the years 1981-90, Sørensen and Yosha (1996) conclude that cross-border asset ownership contributes much more toward smoothing the cross-sectional variability of annual consumption in the US than in the EU.

The dismantling of EU capital-account restrictions under the Single European Act probably has gone part way to diminish the contrast between the US and Europe. Furthermore, the introduction of the euro will greatly enhance the integration and efficiency of the European capital market. But fully catching up to the US will take time, and depends on the further opening of domestic European financial markets. In the meantime, an important private insurance mechanism of the US currency union seems to be less developed in the future EMU. As long as Europe's capital markets lag behind those of the US, the need for the government to provide substitute insurance is correspondingly greater.

\subsection{Fiscal transfers in existing currency unions}

Since at least the work of Ingram (1959), economists have recognized the role of interregional fiscal transfers in equilibrating regional balances of payments within currency unions. The question was placed squarely on the European agenda by the MacDougall Report (Commission of the European Communities 1977), although the issue had been raised years earlier in the Werner Report. MacDougall and his colleagues argued that in existing industrialized currency unions, both fiscal redistribution to offset long-run regional income differentials, and stabilizing fiscal 
transfers aimed at providing a short-term cushion against cyclical shocks, are substantial. Their report suggested (p. 49) that on average roughly 40 percent of any long-run regional per capita income disparity is eliminated by equalization policies. They also contended (p. 35) that in the UK and France, 'as much as one-half to two-thirds of a short-term loss of primary income due to, for example, a fall in a region's external sales may be offset through the public finance system, and much the same may be true of regions in other modern integrated economies'.

Although the MacDougall Report regarded international fiscal flows at that level as impracticable for the near term, it suggested (pp. 20-1) that a European Community budget on the order of five to seven percent of community GNP, providing for net transfers between member states both for equalization and stabilization purposes, might provide sufficient support to allow Europe to proceed to monetary unification: 'A federation with these special characteristics would facilitate creation of a monetary union. Existing national federations enjoy such union internally, and its maintenance is powerfully assisted by the largely automatic equalising and stabilising interregional flows through the channels of federal finance.' Importantly to the argument we shall make below, the MacDougall Report regarded redistribution as well as stabilization as vital elements in sustaining a currency union. In the authors' view, a country giving up substantial fiscal as well as monetary autonomy within a single market served by a single money might be running a greater risk of permanent economic decline (p. 25).

The study of US fiscal federalism by Sala-i-Martin and Sachs (1992) moved the discussion to a more rigorously quantitative level. They regressed log-levels of US census regions' relative transfers and taxes on the log-level of relative personal income in the region. The bottom-line finding is that on average across regions during the years $1970-88$, federal taxes and transfers 
together offset fully 40 percent of a one-dollar shock to local personal income. Taken at face value, the result would imply that even the US currency union, with its relatively footloose labor force, relies heavily on fiscal transfers to offset regional shocks (though not as heavily as a credulous reader of the MacDougall Report might have predicted).

Von Hagen (1992) argues that the Sala-i-Martin and Sachs (1992) regression of relative tax and transfer levels on relative income levels confounds the stabilization role of transfers with their redistributive role. He proposes to regress year-to-year tax and transfer changes on income changes to get at the stabilization effect, and to regress yearly levels of taxes and transfers on yearly levels of incomes to get at the redistributive effect. Von Hagen's estimates over a 1981-86 sample of US states look at the response of net fiscal inflows to Gross State Product rather than personal income before taxes (the two differing primarily because of asset income from other states). Thus the results are not immediately comparable to those of Sala-i-Martin and Sachs. He finds that short-run stabilizing role of net transfers--their response to a one-year change in GSP-amounts to only ten cents on the dollar. Long-run redistribution in the US is, however, estimated to be very large, roughly 47 cents on the dollar.

Subsequent researchers have continued to reconsider the US experience, but also have added data on other countries. Goodhart and Smith (1993) apply von Hagen's (1992) specifications to US, Canadian, and UK data, finding stabilization effects similar to his for the US and Canada, but somewhat larger (21 cents on the dollar) for the UK. They find, however, that the estimated redistributive effects are quite close to the stabilization effects. They argue that these estimates are likely to underestimate the true effects, since von Hagen's measure of taxes omits social security contributions. Pisani-Ferry, Italianer, and Lescure (1993) revisit the United 
States and introduce France and Germany, using a simulation methodology based on the characteristics of national fiscal systems, rather than regression analysis. The find a seventeen cents on the dollar offset to a decline in gross regional product in the US, and offsets roughly twice that size for France and Germany. The huge difference compared with the US stems in large part from the operation of the French and German unemployment insurance and social security systems, together with the system of interregional grants (Länderfinanzausgleich) in Germany.

Returning to econometrics, Bayoumi and Masson (1995) analyze the US and Canada. (In Canada, as in Germany, interregional equalization is a constitutional principle.) Using a specification somewhat different from von Hagen's, and pursuing estimation of stabilization via yearly differences but of redistribution via long-run average levels, they find a 31 percent stabilization effect and a 22 percent redistribution effect for the US. These effects refer to percentages of shocks to personal income, not GSP. For Canada, where federal taxes are less important and provinces exercise considerable discretion fiscal policy, the stabilizing effect fiscal flows is only seventeen percent. However, the extensive Canadian equalization system results in a redistributive effect of 39 percent. ${ }^{20}$

Mélitz and Zumer (1997) try to reconcile these conflicting conclusions by applying uniform accounting procedures and a common econometric methodology to the US, Canada, the UK, and France. Their estimated stabilization coefficients with respect to personal income are around twenty percent for the US, UK, and France, but only ten to fourteen percent for Canada. They estimate a 38 percent long-run equalization of personal incomes in France, an equalization of 26 percent in the UK, and equalizations around 17 percent in Canada and the US. Their estimate of Canadian redistribution is much lower than the 39 percent 'headline' estimate of 
Bayoumi-Masson. The explanation is their exclusion of federal grants to provincial governments from their estimates of personal-income stabilization. Mélitz and Zumer argue that such grants belong only in estimates of output stabilization. One might justify the Bayoumi-Masson accounting, however, by arguing that direct grants from the centre or from other localities allow local governments to lower taxes or increase their provision of public goods and services valued by consumers.

Thus, a considerable range of estimates remains for some countries. Does any consistent pattern emerge? Coming back to the US, a stabilization coefficient with respect to personal income of twenty percent--a number not inconsistent with von Hagen's (1992) estimate of ten percent with respect to GSP--seems to emerge from the literature as a rough consensus figure. Interestingly, Asdrubali et al. (1996), who explain empirically the cross-sectional correlation of per capita GSP and per capita state consumption, present estimates that imply a US stabilization coefficient of 21 percent with respect to personal income. The extent of redistribution among US states appears to be close to that figure as well, although there is less convergence in the literature. For Canada redistribution seems to be higher, and stabilization lower than in the US, though the latter result is explained by Canada's more decentralized fiscal system. Such evidence as is available for France, Germany, and the UK indicates a higher degree of stabilization and/or redistribution compared with the 'twenty-twenty' standard of the US, especially in the two continental countries. ${ }^{21}$ The continuing transfer flow from western to eastern Germany is a conspicuous example of interregional redistribution.

In assessing the role of transfers, it is important to remember that their importance in stabilizing labor incomes might be disproportionately large, due to the limited capital-market 
access of those with little financial wealth. Atkeson and Bayoumi (1993) confirm that in the US, fiscal transfers play a larger role than asset income in insuring labor income. A related point is that continental European financial markets have provided more limited opportunities for diversification in general than those of the US, making fiscal transfers more valuable at the margin.

\subsection{Stabilization, redistribution, and transfer dynamics}

The textbook case of complete capital markets--in which all risks can be marketed--provides a useful benchmark from which to assess the roles of government transfers in the realistic case where asset markets are far from complete. In complete markets, any uncertain contingency, whether it has a permanent or temporary effect, can be insured against. Events that are perfectly predictable cannot be insured, although borrowing and lending will be available to smooth their effects over time.

In the absence of complete markets, an omniscient government planner might facilitate regional risk sharing by making the contingent interregional transfers that might otherwise have been effected privately. In this case we would view the government as providing insurance services. The government might also make noncontingent transfers based on known structural features of regions--for example, an exogenously fixed payment from an oil-producing region to one without natural resources. These are pure redistributions.

The notion of stabilization used in the empirical fiscal federalism literature does not correspond perfectly to that of insurance, because elements of the tax-and-transfer system that provide insurance against permanent (or highly persistent) shocks may induce fiscal flows that are 
indistinguishable from redistributions once a shock has occurred. One might instead view the proper stabilizing function of fiscal transfers as that of partially compensating for missing interregional insurance markets. ${ }^{22}$ In that case, however, the redistributive effects as estimated in the literature will also tend to capture the stabilization function in its response to permanent or long-lived shocks. Estimated redistributive coefficients would not be irrelevant to the question of stabilization, although it might be hard to distinguish their stabilization and true redistributive components. At the same time, the stabilization coefficients estimated by standard approaches might fail to capture lags in stabilizing fiscal flows (see, e.g., Eichengreen's 1991 case study of Michigan in the early 1980s).

These factors motivate the search for a dynamic fiscal-flow model in which pure redistribution can be separated empirically from transfers that provide insurance against idiosyncratic shocks. ${ }^{23}$ To that end we propose a bivariate VAR specification based on the same variables that Bayoumi and Masson (1995) and Mélitz and Zumer (1997) analyze. Denote by $y_{i, t}$ region $i$ 's relative per capita personal income in period $t$, that is, the log of regional per capita personal income less that of national personal per capita income. Let $y_{i, t}^{a}$ denote relative available per capita income, defined in terms of per capita personal income less tax outflows from the region, plus transfer inflows. ${ }^{24}$ The VAR specification we propose is

$$
\begin{aligned}
y_{i, t}^{a}= & \alpha_{i}+(1-\gamma) y_{i, t}+b_{11}(L) y_{i, t-1}+b_{12}(L) y_{i, t-1}^{a}+\epsilon_{1 i, t}, \\
y_{i, t} & =\beta_{i}+b_{21}(L) y_{i, t-1}+b_{22}(L) y_{i, t-1}^{a}+\epsilon_{2 i, t},
\end{aligned}
$$


where the lag polynomials $b_{i j}(L)$ imply two lags, that is, all are linear functions of the lag operator $L$ (which assigns to any variable its value the period before). In this setup, we assume that the innovation in the second equation is an exogenous change in regional relative income per head, which affects net transfers, and hence available income, but is not itself affected by the change in transfers in the same period.

We take the ordinary least squares estimate of $\gamma$ in equation (1) as measuring the contemporaneous stabilizing effect of the transfer. Here, this coefficient measures the response of fiscal flows to an unanticipated relative income shock, whereas the coefficient usually associated with stabilization in the literature applies to any relative income change, expected or not. The VAR setting allows also us to trace the entire dynamic response of income and available income, and hence of transfers (which can be approximated as $y_{i, t}^{a}-y_{i, t}$ ). Notice we are assuming that, once correction is made for region-specific means, relative per capita income is a stationary or mean-reverting variable: we do not contemplate long-run regional divergence.

The estimated VAR also allows us to estimate long-run redistribution. In this setting the estimate does not depend on random realizations of per capita regional income. Equations (1) and (2) allow one to calculate the steady-state (unconditional mean) values $\hat{y}_{i}^{a}$ and $\hat{y}_{i}$ for each region, as functions of the region-specific constants $\alpha_{i}$ and $\beta_{i}$ and the other equation coefficients. A regression of $\hat{y}^{a}{ }_{i}$ on $\hat{y}_{i}$ across regions $i$ yields the coefficient $1-\delta$, where $\delta$ denotes the coefficient of long-run redistribution.

Table 8 reports our estimates of the redistribution and stabilization coefficients for Canada (1971-1995), Italy (1979-93), and the US (1969-85), where for the US we have simply used the 
same data as Bayoumi and Masson (1995).

\begin{tabular}{|l|c|c|}
\hline \multicolumn{3}{|c|}{ Table 8: Redistributive and Stabilizing Effects of Transfers, Canada, US, and Italy } \\
\hline Country & 0: Long-run redistribution & $\gamma$ : First-year stabilization \\
\hline Canada & 0.53 & 0.13 \\
(federal taxes, transfers, grants) & $(0.03)$ & $(0.02)$ \\
\hline $\begin{array}{l}\text { United States } \\
\text { (federal taxes, transfers, grants) }\end{array}$ & 0.19 & 0.10 \\
\hline Italy & $(0.03)$ & $(0.01)$ \\
(social insurance system) & 0.08 & 0.03 \\
\hline Standard errors are given in parentheses. & $(0.02)$ & $(0.03)$ \\
\hline
\end{tabular}

For Canada, our stabilization effect is quite similar to the estimates of Mélitz and Zumer (1997), and slightly below that of Bayoumi and Masson (1995). But the redistributive effect that our method measures is much higher than those in the literature. For the US, we find only about half the stabilization effect suggested by recent studies that have used personal income as the regional activity variable. (However, the stabilization effect rises from 10 to 12 percent the period after the shock first occurs.) The US redistribution coefficient is, however, close to the canonical twenty percent figure. Finally, for Italy the redistribution coefficient is significant but very small (although the extent of regional income inequality is large). The estimated first-year stabilization effect, at only 3 percent, is insignificant, statistically and economically. However, as we have noted, our Italian data give a very partial picture of total fiscal flows.

Table 9 provides a more complete picture of the dynamic response of relative transfers to a relative regional income shock. The main point to notice is that the transfer effect of the income shock is quite persistent, taking in all cases over five years to be reduced by half. In Canada transfers fall back to their baseline more quickly than output does, while the reverse is true in Italy 
and the US. Thus, in Canada the stabilizing role of transfers declines over time for a typically

Table 9: Dynamic Response of Transfers to a Regional Income Shock

\begin{tabular}{|l|c|r|r|r|r|}
\hline Country & Variable & First year & Five years & Ten years & Fifteen years \\
\hline Canada & $\Delta y$ & 1.00 & 0.68 & 0.21 & 0.05 \\
& $\Delta$ trans & -0.13 & -0.07 & 0.00 & 0.00 \\
\hline \multirow{2}{*}{ United States } & $\Delta y$ & 1.00 & 0.27 & 0.07 & 0.02 \\
& $\Delta$ trans & -0.10 & -0.07 & -0.02 & 0.00 \\
\hline \multirow{2}{*}{ Italy } & $\Delta y$ & 1.00 & 0.17 & 0.01 & 0.00 \\
& $\Delta$ trans & -0.03 & -0.03 & -0.01 & 0.00 \\
\hline
\end{tabular}

The variable trans is defined as the log of available relative regional income per capita less the log of relative regional income per capita. The operator $\Delta$ denotes a first difference.

persistent output shock. ${ }^{25}$

The high persistence of stabilizing transfers, even in the US, suggests that their role goes beyond that of temporarily cushioning cyclical shocks. They appear to represent rather long-lived inflows to regions that have suffered macroeconomic reversals, and, as such, facilitate postponement of any necessary adjustment in labor force and relative prices.

\section{Lessons for EMU}

The preceding comparative analysis of North American and European currency unions yields several regularities and contrasts which might be useful in evaluating the future performance and evolution of EMU.

1. Labor mobility is a weaker aid to regional adjustment in Europe than in the US or even in Canada. We see a glacial pace of regional labor-market adjustment accompanied by high and persistent regional employment differentials. 
2. Despite relatively low interregional labor mobility and despite the absence of independent macro policy options for subnational European regions, regional real exchange rate flexibility is not greater than in currency unions with higher labor mobility.

3. Fiscal transfers from booming to depressed regions, both for redistributive and stabilization purposes, play a significant role in all the currency unions we have examined, although their role seems most modest in the US. Transfer flows and the economic shocks to which they respond appear to be quite persistent, making it difficult to draw a sharp line between the long-run redistributive and short-run stabilizing roles of transfers. By providing long-lived fiscal inflows from the rest of the country, existing systems of fiscal federalism in Europe ensure that regions experiencing permanent negative idiosyncratic shocks will be relieved of some of the pressure to adjust.

EMU is an entirely novel experiment in full monetary unification among major political powers without full political unification or an overarching fiscal authority. This feature makes it difficult to predict how EMU might evolve. If EMU develops national adjustment mechanisms similar to those driving regional adjustment within existing currency unions, the preceding list of regularities offers several alternative templates.

At least in the foreseeable future, EMU is unlikely to rely on international labor mobility to any great extent. In post-Schengen Europe as within its constituent states, workers theoretically have full freedom of movement. But the factors that nonetheless limit intranational migration curb international migration even more, and there is the additional barrier of language and custom. Not only are workers in potential source countries reluctant to migrate; in addition, workers in potential host countries are reluctant to welcome foreign competitors. As 'One Market, One 
Money' puts it, 'large-scale labor mobility in the Community is neither feasible, at least not across language barriers, nor perhaps desirable' (Emerson et al. 1992, p. 151). Because intra-European migration on a large scale would be perceived as socially disruptive, EMU is likely to put in place incentives to remain at home--a point we elaborate below.

Does this mean that national price and wage levels in EMU will become more flexible to accommodate needed national adjustments in real exchange rates? The experiences of existing continental currency unions provide no supporting evidence, nor do those of countries that have long pegged to the Deutsche mark. The heightened perception of a single market that the euro will bring could even promote a greater tendency toward EMU-wide wage bargaining or coverage. As Eichengreen (1992) notes, desires to limit cross-border migration might also contribute to this outcome. The labor-market experience of East Germany after unification is an extreme one that does not fully apply across different European countries, but it carries a relevant warning.

From a political viewpoint, sharp movements in intra-EMU wages or competitiveness levels would undermine support for the single market as surely as sharp exchange rate movements between member states. Workers in countries that had lost competitiveness would allege unfair competition, especially in the face of plant closures and shifts of capital to low-wage EMU countries. Relatively immobile firms might call for protcction. Such developments, like the threat of migration, would sharpen EMU leaders' interest in promoting wage convergence--even at the cost of economic efficiency. For all of these reasons, we doubt that EMU will display substantially greater flexibility in internal real exchange rates than its constituent members currently do.

Laboring under these constraints on adjustment, the EU will eventually face strong 
pressures to expand its centralized fiscal functions in the direction of inter-country stabilization transfers. Given the generally high persistence of macroeconomic shocks in Europe, especially shocks at the national level, stabilization payments are likely to play a substantial ex post redistributive role as well. There are several reasons to expect this development.

A country that joins a currency union provides its partners with a public good by expanding the domain over which the single currency is used. Correspondingly, its claim on community protection against persistent or even permanent shocks can be legitimized. The Werner Report took it for granted that 'an increase in financial intervention effected at Community level' would be a necessary adjunct to monetary union, and the MacDougall Report argued the point in detail seven years later ${ }^{26}$ Van Rompuy et al. (1991, p. 119) contend that 'States agree on the centralization of competences and on the discipline implied by the adherence to the EMU in exchange for redistributive mechanisms'.

Indeed, this has been the pattern already: the Maastricht Treaty's Protocol on Economic and Social Cohesion, which set up the Cohesion Fund, and the consequent 1992 increase in Structural Funds, were essential components in sealing the final agreement on EMU. Countries that run into severe economic difficulties under EMU may well be able to lobby successfully for additional side-payments. To the extent that the stability pact limits national fiscal responses and social safety nets, pressures on Brussels will be heightened further, as argued by von Hagen and Eichengreen (1996). Attempts to extend EU political or economic integration will provide ample further opportunities for bargaining over transfers.

Large intra-EMU unemployment and income differentials, coupled with some scale-back of existing support systems for the unemployed and indigent, would create incentives for 
substantial migrations--migrations which, as we have argued, EMU leaders could perceive as politically unacceptable. Incipient migratory pressures, and the consequent fear of social strife, would in practice be the most compelling reason for EU leaders to extend the transfer system. Examples from existing currency unions abound. Courchene (1993) describes the role of the Canadian transfer system in keeping unemployed workers in the poorer Atlantic provinces. Within Italy, northward migration flows out of the Mezzogiorno have declined sharply since the early 1970 s as a result of higher transfers to the south (as well as enforced real wage convergence and housing shortages due to rent controls; see Attanasio and Padoa Schioppa 1991). In the US, welfare programs starting in the Depression have slowed migration out of Appalachia. In Germany wage and fiscal policies have discouraged east-to-west movements of workers. (The prospect that the EU will be enlarged toward the labor-abundant east has already brought into contention the question of redirecting versus enlarging existing transfer facilities.)

There would naturally be serious political resistance to the enlargement of EU transfer programs. As von Hagen (1993, p. 281) observes, an enhanced international transfer facility would not draw political support from sentiments of national solidarity. Indeed, the existing regional support programs of Belgium, Canada, Italy, and other countries plainly strain the national solidarity that remains. Even if a pure insurance system could be designed, the persistence of shocks and transfers might leave the current payers unclear as to their expected future benefits from continuing the arrangement. Such tensions would make an enlarged transfer program politically destabilizing ex post, but might well fail to prevent its creation.

Would an expanded 'European Transfer Union' (ETU) be good or bad for Europe? Obviously the development would be advantageous to the extent that it provided otherwise 
unavailable risk pooling among EMU countries. Van der Ploeg (1991), Wyplosz (1991), and Goodhart and Smith (1993), among many others, have spelled out that advantage, but also draw attention to the considerable moral hazards such inter-country insurance would involve. Workers might view an ETU as a backstop for high wage demands (as occurred in East Germany after unification). Governments might give in more easily to demands for anti-competitive labor-market measures. (Courchene, 1993, p. 140, relates how Quebec during the 1970s maintained a higher minimum wage than other provinces, successfully shifting the costs of its policy onto the federal budget.) In addition, individual incentives for job search at the EU level would be curbed (as intended by some of those who would support setting up an ETU.)

The scope for moral hazard could be reduced in several ways, but probably not eliminated Goodhart and Smith (1993) suggest that adverse incentive effects could be minimized by ensuring that the transfers were temporary. ${ }^{27}$ Since shocks in Europe tend to have persistent effects, however, such transfers would provide only a small degree of risk sharing. If the goal is to provide a meaningful amount of additional insurance against asymmetric shocks, it will be difficult in practice to avoid transfer payments that look, ex post, like long-term redistributions. Even if inward transfers are initially motivated by factors that are believed to be transitory, they will inherit persistence from the persistence of unemployment, and are likely themselves to induce even greater persistence in unemployment, with further positive feedback to transfers (Lindbeck 1995 discusses some plausible mechanisms).

Further dangers come with an ETU. To the extent that financing and administering the plan concentrates greater fiscal authority in Brussels, an ETU would create a more effective political counterweight to the European Central Bank (von Hagen and Eichengreen 1996; 
McKinnon 1997). That evolution could make the ECB more accountable, as the French hope, but in the process could lead to accommodation and other inflationary errors, as the Germans fear.

If one views the prospect of a European transfer union with alarm, what measures might make it less attractive to its proponents? We see four complementary avenues of approach, all subject to some political or technical difficulties, but none unsurmountably problematic.

First, to rethink and relax the excessive deficits procedure and the stability pact as soon as possible after EMU starts. Since these provisions of the EMU constitution reduce local fiscal powers while providing no substitute at the centre, countries encountering difficulties have a natural opening to press for a central fiscal institution. Greater fiscal latitude at the national level would equip countries only to cushion temporary asymmetric shocks, but that in itself would reduce the pressure for an ETU.

Do the costs of giving up the fiscal restraints outweigh these advantages? A positive sideeffect of the Maastricht Treaty's fiscal norms is that they may in the long run promote internal economic reform. However, there is scant evidence that such reforms will go beyond the limited extent they have attained in 1997-98; Eichengreen and Wyplosz (1998) argue that the constant threat of excessive deficits sanctions could even retard reforms. Might not public deficit biases reemerge if there are no fiscal restraints? That is a possibility, but deficit bias would be even less constrained by the capital market if practiced at the EU level. On other issues, the rationale for the fiscal criteria is weak, as argued by Buiter et al. (1993), von Hagen and Eichengreen (1996), and many others. Once an EMU of eleven countries is a fait accompli, much of the original political motivation for the criteria will be gone, and the prospect of amending the pertinent sections of the Maastricht Treaty may appear less daunting. 
As a second measure, the EU's total borrowing power could be limited--a guarantee against fiscal pulls on the center $a$ la Canada. If EMU member states can borrow, there is little justification, for example, for giving the European Investment Bank an expanded role, along the lines feared by von Hagen and Eichengreen (1996).

A third, and very essential task is vigorous internal restructuring--including further reductions in the generosity of pension and other support programs, lower taxes on employment, more hiring and firing flexibility, vigilant financial liberalization, and housing market reform. Such measures would increase each member state's capacity to adjust rapidly to shocks and to deploy fiscal policy when necessary. They would also reduce moral hazards at the individual level. As always, this part of the agenda remains the most difficult to implement in view of the political realities on the ground. In Europe there is extra resistance because policies that open labor markets to domestic 'outsiders' also allow foreign workers in. However, any resulting migratory pressures would be less problematic in the setting of growth and job creation that these policies would bring about, especially if reform is pursued throughout the EU.

A fourth suggestion comes from the observation the missing markets for human capital insurance provide much of the theoretical basis for beliefs that an ETU might be beneficial. In principle each individual national government could act as a capital-market intermediary for its residents, making insurance payouts to them in the form of higher transfers or lower taxes. To accomplish that end, governments would issue perpetual euro-denominated liabilities indexed to domestic nominal per capita GDP growth. ${ }^{28}$ The proceeds would be invested in an internationally diversified portfolio of assets. In this way each government could lay off some of its GDP risk; its net cash flow would tend to go up when GDP growth was unexpectedly low, just as under an 
ETU. Permanent and transitory shocks alike could be handled. But no central EU institution is needed to carry out the plan.

An advantage of the setup is that each country would need to strive for good macroeconomic performance to maintain favorable terms for marketing its GDP-linked securities. The price of the securities would plummet if a country ever tried to issue enough to make deliberate macroeconomic policy failure attractive. Given its independence, it is unlikely the ECB would ever be tempted in that direction either. Some technicalities would need to be worked out-for example, safeguards against deliberate misreporting of GDP. Finally, the plan's feasibility probably would require a weakening of the Maastricht deficit norms, since the government deficit might become more vulnerable to wide temporary fluctuations.

The alternative scenario we have outlined raises significant challenges for the European Union. EMU is about to be born, however, only because Europe has shown the creativity and determination to meet such challenges in the past. The same qualities will be needed in abundance now to make EMU work. 


\section{Appendix: Data}

All data are at the annual frequency.

\section{A1. Italy}

The regional division adopted for Italy is the standard classification into regioni adopted by the Italian government and by the EU. This definition divides the Italian territory into twenty regions: Piemonte, Valle d'Aosta, Lombardia, Trentino, Veneto, Friuli, Liguria, Emilia, Toscana, Umbria, Lazio, Marche, Abruzzo, Molise, Campania, Puglia, Basilicata, Calabria, Sicilia, and Sardegna. We have divided the region 'Trentino' into its two provinces (Trento and Bolzano), given that the province of Bolzano, being a bilingual province (provincia autonoma), enjoys somewhat greater autonomy.

Labor markets: The regional data on employment, unemployment, total population, and population of working age for the period 1969-95 were collected from the Italian statistical yearbooks (ISTAT, Annuario Statistico Italiano, yearly issues), from ISTAT, Bollettino Mensile di Stastistica, various issues, and from ISTAT, Annuali di Statistiche del Lavoro, yearly issues. Data on CIG, available only for the period 1984-94, were collected from ISTAT, Anmuario Statistico Italiano.

Prices and GDP: Data on regional prices are the GDP deflators reported in Annuario Statistico Italiano (1969-95). Data on regional GDP (1977-92) were collected from the ISTAT publication Le Regioni in Cifre (1994).

Social insurance: Data on transfers to persons and on contributions to the social insurance system are taken from the Annuario Statistico. For the period 1977-94 the variable is defined as the value in billions of 1991 lire of the contributi e prestazioni degli enti previdenziali, covering 
all social welfare spending (pensions, unemployment insurance, health care). The definition of the variable 'net transfers' is the value (in million 1991 lire per capita) of the transfers received by a region for social insurance minus the contributions paid by the region to the central government.

\section{A2. Germany}

The regional unit for the analysis of German data is the Land. As we have considered only the western Länder, our analysis includes the following eleven regions: Schleswig-Holstein, Hamburg, Niedersachsen, Bremen, Nordrhein-Westfalen, Hessen, Rheinland-Pfalz, BadenWürttemberg, Bayern, Saarland, and West Berlin.

Labor market: Data on employment and unemployment over 1970-94 for each Land were collected from the Bundesanstalt fur Arbeit, data on working-age population (1970-93) come from the Statistisches Jahrbuch, various issues, and from the Statistisches Bundesamt.

Prices and GDP: GDP deflators and nominal GDP at the Land level for 1970-1994 were provided by the Finanzamt Baden-Württemberg. Total population data also come from this source.

Fiscal variables: The data on total direct and indirect taxes collected by the federal government in each Land are from the Statistisches Jahrbuch, various issues. The data on net transfers occurring across Länder under the Länderfinanzausgleich (LFA or "round of tax redistribution") are used to calculate the net tax "payments" from each Land to the federal government. In particular we subtracted from the taxes any net amount that the $L a n d$ receives from other Länder during the LFA, while we add any negative amount. These data were taken from the Statistisches Bundesamt, various issues. 


\section{A3. Canada}

The ten provinces constituting the Canadian Federation are the geographical units of our regional analysis. They are: Newfoundland, Prince Edward Island, Nova Scotia, New Brunswick, Quebec, Ontario, Manitoba, Saskatchewan, Alberta, and British Columbia.

All data for the Canadian provinces as well as for the entire country were obtained from the "Cansim" data base at the following world wide web address: http://www.statcan.ca/cpibin/Cansim.

Labor market: Data on employment and the labor force were taken from the directory Socio-Economic Statistics. We used the yearly series for total population, 'population older than 15', 'labor force older than 15 ', and 'employment older than 15 '. These series are available for 1976-96 for each province and for the country as a whole.

Prices and personal income: Data on prices are the yearly implicit GDP deflator for each province, available for 1971-96. The data on personal income for the period 1971-1996 were also purchased from the "Cansim" website. Tamim Bayoumi and Paul Masson kindly made available to us the data set that they used in their 1995 paper. Data on personal income, personal transfers, taxes and federal grants to local government are available in this data set for the period 1965 1985. For a more detailed description of these data sec the data appendix of Bayoumi and Masson (1995).

Fiscal variables: Total federal taxes for each province have been calculated as the total of direct federal taxes from persons. The total federal transfers are the sum of the transfer payments to persons and to local government. These, valued in thousands of 1991 Canadian dollars per 
capita, have been used to calculate the 'net transfers' to a province as the difference between the transfers received from the federal government and the taxes paid.

\section{A4. United Kingdom}

The eight regions into which England is divided plus Wales, Scotland, and Northern Ireland are the geographical regional units considered for the UK. The following is the complete list: South East, East Anglia, South West, West Midlands, East Midlands, York and Humberside, North West, North, Wales, Scotland, and Northern Ireland.

Labor market: Data on employment, unemployment, and working-age population for each region for the period 1969-1994 come from the Yearly Statistical Abstract (yearly issues) and from the Employment Gazette (various issues) and IIistorical Supplement of the Employment Gazette (various issues), London, Employment Department.

\section{A5. United States}

The geographical regional units for the analysis of US labor markets are the 50 states plus the District of Columbia.

Labor market: Data on employment, unemployment and working-age population for the period 1976-1990 have been taken from the data set used by Olivier Blanchard and Larry Katz in their 1992 paper. We thank them for providing these data, which we have updated for 1991-95 using information from the Geographic Profile Data Set.

Personal income and transfers: Total taxes paid to the federal government are defined as the sum of personal taxes and social insurance payments. Total transfers from the federal government are the sum of personal transfers and transfers to local governments. The data on personal income, taxes, and transfers for the period 1969-1985 were taken from the data set provided by Tamim Bayoumi 
and Paul Masson. For a more detailed description of these data see the appendix to Bayoumi and Masson (1995)

\section{A6. International GDP deflator and exchange rate data}

Year-average figures from OECD, Fiscal Positions and Business Cycles on Diskette, 77/1. European cross rates were deived from dollar exchange rates using triangular abitrage. 


\section{References}

Asdrubali, P., B. E. Sørensen, and O. Yosha (1996). 'Channels of Interstate Risk Sharing: United States 1963-1990', Quarterly Journal of Economics.

Atkeson, A., and T. Bayoumi (1993). 'Do Private Capital Markets Insure Regional Risk? Evidence from the United States and Europe', Open Economies Review.

Attanasio, O. P. and F. Padoa Schioppa (1991). 'Regional Inequalities, Migration and Mismatch in Italy, 1960-86', in F. Padoa Schioppa (ed.) Mismatch and Labor Mobility, Cambridge University Press.

Bayoumi, T. and B. Eichengreen (1996). 'Operationalizing the Theory of Optimum Currency Areas', Centre for Economic Policy Research Discussion Paper Series No. 1484 (October).

Bayoumi, T. and P. R. Masson (1995). 'Fiscal Flows in the United States and Canada: Lessons for Monetary Union in Europe', European Economic Review.

Bertola, G. and A. Ichino (1995). 'Crossing the River', Economic Policy.

Blanchard, O. J. and L. F. Katz (1992), 'Regional Evolutions', Brookings Papers on Economic Activity.

Boadway, R. W. and P. A. R. Hobson (1993). Intergovernmental Fiscal Relations in Canada, Canadian Tax Foundation/L'Association Canadienne d'Études Fiscales.

Buiter, W., G. Corsetti, and N. Roubini (1993). 'Excessive Deficits: Sense and Nonsense in the Treaty of Maastricht', Economic Policy.

Commission of the European Communities (1977). 'Report of the Study Group on the Role of Public Finance in European Integration', Economic and Financial Series No. A13, Brussels (April).

Corden, W. M. (1972). Monetary Integration, Princeton Essays in International Finance No. 93 (April)

Costello, D. (1993). 'The Redistributive Effects of Interregional Transfers: A Comparison of the European Community and Germany', European Economy, Reports and Studies No. 5

Courchene, T. J. (1993). 'Reflections on Canadian Federalism: Are There Implications for the European Economic and Monetary Union?', European Economy, Reports and Studies No. 5.

Davis, S. J., P. Loungani, and R. Mahidhara (1997). 'Regional Labor Fluctuations: Oil Shocks, 
Military Spending, and Other Driving Forces', International Finance Discussion Papers No. 578, Board of Governors of the Federal Reserve System, March.

Debelle, G. and O. Lamont (1997). 'Relative Price Variability and Inflation: Evidence from U.S. Cities', Journal of Political Economy.

Decressin, J., and A. Fatás (1995). 'Regional Labor Market Dynamics in Europe', European Economic Review.

De Grauwe, P. and W. Vanhaverbeke (1993). 'Is Europe an Optimum Currency Area? Evidence from Regional Data', in P. R. Masson and M. P. Taylor (eds.) Policy Issues in the Operation of Currency Unions, Cambridge University Press.

Eichengreen, B. (1990). 'One Money for Europe? Lessons from the US Currency Union', Economic Policy.

(1991). 'Is Europe and Optimum Currency Area?', National Bureau of Economic Research Working Paper No. 3579, January. (1992). 'Comment', Brookings Papers on Economic Activity. (1993a). 'Labor Markets and European Monetary Unification', in P. R. Masson and M.

P. Taylor (eds.) Policy Issues in the Operation of Currency Unions, Cambridge University Press. (1993b). 'European Monetary Unification', Journal of Economic Literature.

Eichengreen, B. and C. Wyplosz (1998). 'The Stability Pact: Minor Nuisance, Major Diversion', Economic Policy (this issue).

Emerson, M. et al. (1992). One Market, One Money: An Evaluation of the Potential Benefits and Costs of Forming an Economic and Monetary Union, Oxford University Press.

Engel, C. and J. H. Rogers (1995). 'Regional Patterns in the Law of One Price: The Roles of Geography vs. Currencies', National Bureau of Economic Research Working Paper No. 5395 (December).

Eurostat (various years). Regional Statistical Handbook.

Forni, M. and L. Reichlin (1997). 'National Forces and Local Economies: Europe and the United States', Centre for Economic Policy Research Discussion Paper No. 1632 (April).

Goodhart, C. A. E., and S. Smith (1993). 'Stabilization', European Economy, Reports and Studies 
No. 5 .

Green, D. A. and W. C. Riddell (1997). 'Qualifying for Unemployment Insurance: An Empirical Analysis', Economic Journal.

Hinshaw, R. (1951). 'Currency Appreciation as an Anti-Inflationary Device', Quarterly Journal of Economics.

Hughes, G. and B. McCormick (1987). 'Housing Markets, Unemployment and Labor Market Flexibility', European Economic Review.

Ingram, J. C. (1959). 'State and Regional Payments Mechanisms', Quarterly Journal of Economics. (1973). The Case for European Monetary Integration, Princeton Essays in International Finance No. 98 (April).

Kenen, P. B. (1995). Economic and Monetary Union in Europe: Moving beyond Maastricht, Cambridge University Press.

Krugman, P. (1993). 'Lessons of Massachusetts for EMU', in F. Torres and F. Giavazzi (eds) Adjustment and Growth in the European Monetary Union, Cambridge University Press.

Lindbeck, A. (1995). 'Hazardous Welfare-State Dynamics', American Economic Review, Papers and Proceedings.

McCormick, B. (1997). 'Regional Unemployment and Labor Mobility in the UK', European Economic Review.

McKinnon, R. I. (1963). 'Optimum Currency Areas', American Economic Review. (1997). 'Market-Preserving Fiscal Federalism in the American Monetary Union', in M. I. Blejer and T. Ter-Minassian (eds.) Macroeconomic Dimensions of Public Finance: Essays in Honour of Vito Tanzi, Routledge.

Masson, P. R. and M. P. Taylor (1993). 'Currency Unions: A Survey of the Issues', in P. R. Masson and M. P. Taylor (eds.) Policy Issues in the Operation of Currency Unions, Cambridge University Press.

Mélitz, J. and F. Zumer (1997). 'Regional Redistribution and Stabilization by the Center in Canada, France, the UK and the US', CREST-INSEE and OFCE, mimeo (November).

Nickell, S. (1997). 'Unemployment and Labor Market Rigidities: Europe versus North America', Journal of Economic Perspectives. 
Obstfeld, M. (1998). 'Open-Economy Macroeconomics: Developments in Theory and Policy', Scandinavian Journal of Economics.

OECD (1990). OECD Employment Outlook, Paris (July).

Oswald, A. (1996). 'A Conjecture on the Explanation for High Unemployment in Industrialised Nations: Part I', University of Warwick, mimeo.

Peri, G. (1997). 'Do Civic Spirit and Economic Diversity Help Growth? Evidence from Italian Cities and Provinces, 1961-1991', University of California, Berkeley, mimeo.

Persson, T. and G. Tabellini (1996). 'Federal Fiscal Constitutions: Risk Sharing and Redistribution', Journal of Political Economy.

Pisani-Ferry, J., A. Italianer, and R. Lescure (1993). 'Stabilization Properties of Budgetary Systems: A Simulation Analysis', European Economy, Reports and Studies No. 5.

Poloz, S. (1990). 'Real Exchange Rate Adjustment between Regions in a Common Currency Area', Bank of Canada, mimeo (February).

Sala-i-Martin, X. and J. Sachs (1992). 'Fiscal Federalism and Optimum Currency Areas: Evidence for Europe from the United States', in M. B. Canzoneri, V. Grilli, and P. R. Masson (eds.) Establishing a Central Bank: Issues in Europe and Lessons from the US, Cambridge University Press.

Shiller, R. J. (1993). Macro Markets: Creating Institutions for Managing Society's Largest Economic Risks, Oxford University Press.

Sørensen, B. E. and O. Yosha (1996). 'International Risk Sharing and European Monetary Unification', Foerder Institute Working Paper No. 40-96, Tel Aviv University (December). Steinherr, A., ed. (1994). 30 Years of European Monetary Integration from the Werner Plan to $E M U$, Longman.

van der Ploeg, F. (1991). 'Macroeconomic Policy Coordination Issues during the Various Phases of Economic and Monetary Integration in Europe', European Economy, Special Edition No. 1. van Rompuy, P., F. Abraham, and D. Heremans (1991). 'Economic Federalism and the EMU', European Economy, Special Edition No. 1.

Vaubel, R. (1976). 'Real Exchange-Rate Changes in the European Community: The Empirical Evidence and Its Implications for European Currency Unification', Weltwirtschaftliches 
Archiv.

(1978). 'Real Exchange-Rate Changes in the European Community: A New Approach to the Determination of Optimum Currency Areas', Journal of International Economics.

Viñals, J. and J. F. Jimeno (1996). 'Monetary Union and European Unemployment', Banco de España, Servicio de Estudios, Documento de Trabajo No. 9624.

von Hagen, J. (1992). 'Fiscal Arrangements in a Monetary Union: Evidence from the US', in D. E.

Fair and C. de Boissieu (eds.) Fiscal Policy, Taxes, and the Financial System in an Increasingly Integrated Europe, Kluwer.

(1993). 'Monetary Union and Fiscal Union: A Perspective from Fiscal Federalism', in

P. R. Masson and M. P. Taylor (eds.) Policy Issues in the Operation of Currency Unions, Cambridge University Press.

von Hagen, J. and B. Eichengreen (1996). 'Federalism, Fiscal Constraints, and European Monetary

Union', American Economic Review, Papers and Proceedings.

von Hagen, J. and G. W. Hammond (1997). 'Insurance against Asymmetric Shocks in a European Monetary Union', in J.-O. Hairault, P.-Y. Hénin, and F. Portier (eds.) Business Cycles and Macroeconomic Stability: Should We Rebuild Built-in Stabilizers?, Kluwer.

von Hagen, J. and M. J. M. Neumann (1994). 'Real Exchange Rates within and between Currency Areas: How Far Away is EMU?', Review of Economics and Statistics.

Weber, A. (1997). 'Sources of Purchasing Power Parity Disparities: Europe versus the United States', Universität Bonn, mimeo (February).

Wyplosz, C. (1991). 'Monetary Union and Fiscal Policy Discipline', European Economy, Special Edition No. 1. 


\section{Endnotes}

We thank Reza Baqir, Ryan Edwards, and Stefan Palmqvist for excellent research assistance. Tamim Bayoumi, Giovanni Favara, Ingo Fender, Larry Katz, Paul Masson, Chris Salmon, and Till von Wachter offered valuable help in locating and organizing data. Olivier Blanchard, David Card, Barry Eichengreen, Antonio Fatás, Peter Kenen, Barry McCormick, Jacques Mélitz, Andrew Oswald, Frédéric Zumer, and especially Jürgen von Hagen have made many very helpful suggestions, as did participants in the October 1997 Economic Policy panel meeting in Bonn and the Berkeley Labor Lunch. All errors and opinions are our own. Research support was provided by the National Science Foundation (through a grant to the National Bureau of Economic Research), the Alfred P. Sloan Foundation, and the Center for German and European Studies at the University of California, Berkeley.

1. One of the early academic discussions is Corden (1972), which was inspired by the Werner Report and sets out many of the themes that the subsequent literature explores. Ingram (1973) is another notable early contribution. A recent comprehensive review of issues is contained in Kenen (1995).

2. In the specific context of EMU, however, the prospect that the stability pact will hamstring national fiscal policies brings more urgency to the question of temporary shocks. See Eichengreen and Wyplosz (1998) for analysis of the stability pact's possible effects.

3. McCormick (1997) discusses UK regional employment trends.

4. A quick look at two other large European countries confirms the trend toward regional unemployment divergence on the continent. The standard deviation of regional unemployment rates in 19 French départements has increased from 1.1 percent in 1980 to 3.7 percent in 1993 
(compare with figure 1), while the average national unemployment rate has increased from 6 to 11 percent. For Spain the evolution seems even more unbalanced, as the standard deviation of 17 regional unemployment rates has increased from 3 percent in 1985 to 5.2 percent in 1993 with little net change in national average unemployment (Spain's unemployment rate stood near 21 percent in both years; see Eurostat, various years).

5. The results are: Canada, slope $=0.78, t$-statistic $=5.20, R^{2}=0.75 ;$ Germany, slope $=0.77, t-$ statistic $=3.65, R^{2}=0.58 ;$ Italy, slope $=1.35, t$-statistic $=6.42, R^{2}=0.68 ;$ United Kingdom, slope $=0.60, t$-statistic $=8.77, R^{2}=0.79 ;$ United States, slope $=0.26, t$-statistic $=2.50, R^{2}=$ 0.15. Eichengreen $(1990$, p. 160) finds that unemployment rates in US regions are less serially correlated than the aggregate unemployment rates of European countries. He interprets the finding as evidence of slower labor-market adjustment in Europe. Here, we have shown that the empirical result carries over to regional unemployment rates outside the US.

6. The distinction between means and deviations cannot always be drawn sharply, as benefits administration may respond endogenously to local unemployment, with further feedback effects on unemployment duration. In Canada, for example, the duration of unemployment benefits in a province and the minimum prior work requirement to qualify for benefits depend on the level of the provincial unemployment rate. See Green and Riddell (1997).

7. The left-hand variable in the regression is the difference between average annual regional inflation and average annual national inflation (in percent per year). The right-hand variable is the average regional unemployment rate less the national average (in percent). Results are: Canada $(1976-95)$, slope $=-0.07, t$-statistic $=-0.62, R^{2}=0.06$; Germany $(1976-95)$, slope $=0.01, t$ statistic $=0.35, R^{2}=0.01 ;$ Italy $(1977-94)$, slope $=-0.03, t$-statistic $=-2.46, R^{2}=0.27$. 
8. The left-hand variable in the regression is the per capita net transfer inflow in thousands of 1991 ECU. The right-hand variable is the average regional unemployment rate less the national average (in percent). Results are: Canada (1976-95), slope $=0.03, t$-statistic $=3.12, R^{2}=0.54$; US (1976-85), slope $=0.10, t$-statistic $=2.01, R^{2}=0.05 ;$ Italy $(1977-94)$, slope $=0.05, t$-statistic $=3.57, R^{2}=0.42$. The transfer data for Canada, the US, and Italy, which we also use in econometric analysis in section 5, are not comparable, as those for Italy include social insurance payments only, and exclude, for example, flows related to tax payments. See the data appendix for details. We do not graph our German data, which are also severely limited.

9. In Italy the official data on unemployment underestimate its true extent because of the Casa Integrazione Guadagni (CIG) program, which covers part of the wages of workers who otherwise might be laid off (see, for example, Bertola and Ichino 1995). Since CIG payments are quite persistent, classifying workers on CIG as unemployed would raise the correlation between social insurance inflows and true unemployment. Of course, many who are officially unemployed work in the underground economy. Notice that by entering the underground economy and evading taxes, officially unemployed workers automatically generate a net fiscal transfer into the region where they operate.

10. A problem with such measurements--indeed, the problem applies to all the subnational evidence discussed in this paper--is that constitutionally recognized regional units are based on politico-historic rather than economic boundaries, so that the definition of 'region' has a substantive effect on one's conclusions. Since the available data correspond to these units, however, not much can be done except to control for obviously anomalous cases. The numbers reported in this paragraph refer to Canadian provinces and territories, Italian regioni, eleven west 
German Länder, ten UK regions (excluding Northern Ireland), and 51 US states (including Washington, D.C. as a 'state').

11. The authors also impose the constraint that the national and EU components of unemployment have identical effects across the regions of a country, an assumption that is necessary to conserve degrees of freedom in estimation but which also makes it impossible to distinguish econometrically between truly idiosyncratic regional shocks and national or EU shocks that have divergent regional effects. For the purpose of thinking about regional adjustment problems the two are not that different, as we shall argue later, so the numbers Viñals and Jimeno report are probably a reasonable guide to the frequency of regional shocks that warrant long-run labor reallocation. (They find that country-specific shocks explain much of the variance of EU unemployment when EU shocks are defined so as to have symmetric effects on different countries.)

12. Eichengreen (1993a) also documents that energy prices and national real exchange rates, which may be viewed as largely exogenous to regions, have asymmetrical effects on regional labor markets within the US, the UK, and Italy.

13. Davis, Loungani, and Mahidhara (1997) and Blanchard and Katz (1992) provide alternative estimates for the US based on observable exogenous determinants of regional labor demand, for example, defense contracts. These results are broadly consistent with those for the US that we discuss below. Davis et al. find, however, some sensitivity of the adjustment pattern to the measure of employment used in estimation and suggest a somewhat slower response of migration in response to some shocks.

14. Because of trends in technology or preferences, agglomeration economies, externalities, better 
local institutions, or for social and cultural reasons, some regions tend to attract more workers and firms over the long run while others have a secular tendency to decline in scale. Thus, employment trends may arise. (See Peri 1997 for an empirical study relating long-run employment growth in Italian cities and provinces to local socio-cultural characteristics).

15. In contrast to the general tendency in the literature, Poloz (1990) found relatively high variability in the relative GDP deflators of some Canadian provinces--higher, in some cases, than that between European countries. However, these findings applied mainly to Alberta and Saskatchewan, which are extremely open to trade and are heavy exporters of primary commodities. In such cases, regional real exchange rate movements themselves are largely exogenous shocks, in that they strongly reflect global movements in primary commodity prices. The change in the regional real exchange rate is not primarily the response to some region-specific shock. Also, Poloz's method of normalizing real exchange rate levels over 1980-87 gives an exaggerated appearance of variability for several provinces, since the variability measure he calculates apparently is the standard deviation in the level (not logarithm) of relative price. (Poloz chooses a 1971 base year despite the run up in commodity and especially energy prices since the early 1970s.) Thus, Poloz's volatility figures for the Alberta/Ontario real exchange rate over 1980-87, say, are not readily comparable to those he calculates for the France/Germany rate. 16. The choice of GDP deflators is meant to capture regional export competitiveness. Vaubel (1976, 1978), Eichengreen (1991), and von Hagen and Neumann (1994) study regional CPIbased real exchange rates. De Grauwe and Vanhaverbeke (1993) use data on regional unit labor costs.

17. Using a data sample that includes locations in Europe and an econometric specification that 
controls for distance and trade barriers, Engel and Rogers (1995) find that higher nominal exchange rate volatility between two markets systematically raises inter-market variability in relative prices. See Obstfeld (1998) for a survey. It is not correct, however, to assert that monetary factors have no effect on interregional real exchange rate volatility within currency unions. The evidence is that interregional relative price variability is higher when mean national inflation is higher. Debelle and Lamont (1997) offer a useful capsule review of the evidence, as well as new evidence that the dispersion of prices within US cities is positively related to the citywide inflation rate.

18. The relative price decline within Italy shown in Figure 13 probably does not represent the operation of market forces as described in textbook accounts of regional adjustment. Attanasio and Padoa Schioppa (1991, p. 260) explain why southern Italian CPIs tend to be relatively low, and most of the reasons carry over to GDP deflators: 'The reasons for their low cost of living can probably be found partly in subsidies provided by the Central Government in some services (highways, for instance, are free in the South and not in the North-Centre), partly by cheaper labor in the underground and criminal economy, partly by cheaper rents which are publicly regulated (both for residential and business dwellings) and finally by the lower weight the Southern regions assign to non-agricultural consumption which is everywhere the most expensive and the one whose cost rises more rapidly.' Given the convergence between southern and northcentre nominal wages over the last couple of decades or so (a result of the scala mobile along with other features of Italian wage setting), the implication is that relative real wages in the south actually have risen.

19. We also estimated VARs involving relative per capita GDP as well as relative prices, with 
results broadly similar to those in table 7.

20. While the modern system of Canadian equalization grants dates from 1957, its current incarnation originates in the Constitution Act of 1982 (section 36[2]), which committed the national government to 'the principle of making equalization payments to ensure that provincial governments have sufficient revenues to provide reasonably comparable levels of public services at reasonably comparable levels of taxation.' Under the present system, five provinces--British Columbia, Manitoba, Ontario, Quebec, and Saskatchewan--define a 'standard' level of per capita revenues from 33 specified revenue sources. The standard refers not to actual revenues, but to their hypothetical level at national average tax rates. Provinces with per capita revenues (at national average tax rates) above the standard receive no equalization payments, but make none either. Payments to provinces below the five-province standard (again, at national average tax rates) come from the federal government, which is supposed to bring the poorer provinces up to par. (See Boadway and Hobson 1993.) While this system might be thought to complicate econometric analysis, it is only part of the total tax and transfer system, which includes also federal taxes, social assistance payments, unemployment insurance, and so on. Indeed, the overall long-run relationship between personal income before and after taxes and transfers appears quite linear for Canada, as figure 2 of Bayoumi and Masson (1995) shows.

21. On redistribution in Germany, see Costello (1993).

22. This is the approach taken by Persson and Tabellini (1996), who study the endogenous determination of risk-sharing and redistribution within a federal union. Their simplified model is not immediately applicable to making positive predictions about EMU because it omits certain elements, notably potential labor mobility, likely to be important in practice. 
23. Goodhart and Smith (1993) and Mélitz and Zumer (1997) also stress fiscal dynamics.

24. We focus on personal income, rather than regional product, to evaluate the extra stabilization transfers provide after private portfolio diversification. In terms of the econometrics, regional personal income will be 'more exogenous' than regional product if financial income comes from nationally diversified sources--and simultaneity bias is a potential problem notwithstanding the identifying assumption we make below. For Italy we have no personal income data, so we us regional product instead.

25. We also tried to apply our method to the German fiscal system, but data limitations were particularly severe. The following results, based on total taxes paid by the Länder to the federal government (after correction for Länderfinanzausgleich redistributions), omit transfers and therefore should be interpreted with caution. (See the appendix for more detail on these data.) The tendency emerging was a rather large redistributive role for taxes (a 36 percent coefficient of redistribution). We found a delayed and rather persistent reaction of tax payments to a relativeincome shock (negligible in the first period, 12 percent in the second, 4 percent in the fifth).

26. The Werner Report is reproduced in Steinherr (1994, p. 25).

27. Von Hagen and Hammond (1997) illustrate some of the perils in trying to follow this route. 28. Closely related securities have been proposed and studied by Shiller (1993). Nominal rather than real GDP indexing would protect buyers of the securities against inflation. 